\title{
Evaluating the use of the molybdenite Re-Os chronometer in dating gold mineralization: Evidence from the Haigou deposit, NE China
}

\author{
Degao Zhai ${ }^{1} 2^{*}$, Anthony E. Williams-Jones ${ }^{2}$, Jiajun Liu ${ }^{1}$, David Selby ${ }^{3,4}$, Chao Li ${ }^{5}$, Xiao-Wen Huang ${ }^{6}$, \\ Liang $Q^{6}{ }^{6}$, Donghang Guo ${ }^{1}$
}

${ }^{1}$ State Key Laboratory of Geological Processes and Mineral Resources, China University of Geosciences, Beijing, 100083, China

${ }^{2}$ Department of Earth and Planetary Sciences, McGill University, Quebec, H3A OE8, Canada ${ }^{3}$ Department of Earth Sciences, Durham University, Durham, DH1 3LE, UK

${ }^{4}$ State Key Laboratory of Geological Processes and Mineral Resources, School of Earth Resources, China University of Geosciences, Wuhan, 430074, China

${ }^{5}$ National Research Center of Geoanalysis, Chinese Academy of Geological Science, Beijing 100037, China

${ }^{6}$ State Key Laboratory of Ore Deposit Geochemistry, Institute of Geochemistry, Chinese Academy of Sciences, Guiyang, 550002, China

*E-mail: dgzhai@cugb.edu.cn

Revised Submission to: Economic Geology

With 27 pages, 13 Figures and 1 Tables

10-May-2019 


\section{Abstract}

The Haigou lode gold deposit (>40 t @ $3.4 \mathrm{~g} / \mathrm{t}$ ), which is located near the eastern boundary of the Central Asian Orogenic Belt (CAOB) and the North China Craton (NCC), is one of the largest gold deposits in NE China. Native gold is intergrown with molybdenite and pyrite in auriferous quartz veins hosted by a monzogranite-monzonite stock and locally by Proterozoic gneiss, thereby offering an excellent opportunity to directly date the mineralizing event. Uranium- $\mathrm{Pb}$ age determinations for zircon yielded ages for the monzogranite and monzonite of $327.1 \pm 1.1$ and $329.5 \pm 1.0 \mathrm{Ma}$, respectively. Numerous mafic to felsic dikes, which are crosscut by ore veins (pre-ore), parallel to these veins (possibly syn-ore) or crosscut by them (post-ore), were carefully examined and dated. Their zircon ${ }^{206} \mathrm{~Pb} /{ }^{238} \mathrm{U}$ ages are $318.3 \pm 1.0,310.9 \pm 1.1$, and $134.9 \pm 0.4 \mathrm{Ma}$, respectively, thereby placing the timing of gold mineralization within the relatively large interval of $318.3 \pm 1.0$ to $134.9 \pm 0.4 \mathrm{Ma}$. The age of mineralization was determined directly using the Re-Os method applied to molybdenite. A total of 19 molybdenite samples separated from auriferous quartz veins yielded widely differing Re-Os model ages of 155 to $467 \mathrm{Ma}$, and replicate analyses of individual samples also yielded widely differing ages. Significantly, the wide range is attributable entirely to the results obtained for some coarse-grained molybdenite samples and is interpreted to be due to Re and Os isotope decoupling, the considerable spatial Re heterogeneity, the analytical procedure (e.g., use of small sample aliquots), and the post-ore deformation. Nine of the samples, which are all fine-grained, yielded a robust weighted mean model age of $310 \pm 3 \mathrm{Ma}$, and an isochron age of $309 \pm 8 \mathrm{Ma}$. Thus, the molybdenite Re-Os ages are identical, within uncertainty, to those of the dikes that are parallel to the ore veins, indicating that these dikes were emplaced contemporaneously with the ore and that they and the Haigou gold mineralization are of Late Paleozoic age (ca. $310 \mathrm{Ma}$ ). Finally, a sericite sample obtained from an auriferous vein returned a ${ }^{40} \mathrm{Ar}^{-39} \mathrm{Ar}$ plateau age of $165.3 \pm 1.2 \mathrm{Ma}$, which is much younger than the age of the mineralization constrained by Re-Os age determinations of molybdenite. This indicates that the ${ }^{40} \mathrm{Ar}-{ }^{39} \mathrm{Ar}$ isotope system was reset by post-ore thermal events.

Our new geochronological data provide evidence for Late Paleozoic gold mineralization in Haigou, which makes it the oldest known lode gold deposit in the easternmost CAOB, a finding that has important implications for precious metal mineral exploration in the eastern part of the Solonker-Xar Moron-Changchun-Yanji suture zone between the CAOB and the NCC. This study also indicates that accurate and reproducible molybdenite Re-Os ages representing the true timing of ore deposition need an integrated combination of careful petrography, proper sampling procedures, sufficiently large analyzed aliquots, multiple analyses of individual samples and multiple dating methods.

\section{Introduction}

Direct dating of economic mineralization is essential for establishing robust genetic models of ore formation and understanding the tectonic controls on ore deposition in large metallogenic provinces. Among the currently available radiometric dating methods, the Re-Os method is the only method which can be used to date sulfide minerals directly (Stein et al., 1998, 2001; Selby and Creaser, 2001a; Selby et al., 2002; Morelli et al., 2010; Ootes et al., 2011; Saintilan et al., 2017a, b, 2018). Petrographically- 
constrained, precise and reproducible Re-Os isotope data of mineral separates of individual sulfide/sulfarsenide species permit the ages of discrete mineralizing events to be determined accurately (Saintilan et al., 2018). In particular, it allows the duration of a magmatic-hydrothermal event to be reliably established when combined with state-of-the-art U-Pb age determinations of individual zircons in magmatic rocks (e.g., von Quadt et al., 2011; Chiaradia et al., 2013, 2014; Zimmerman et al., 2014; Chelle-Michou et al., 2015a; Li Y et al., 2017).

Molybdenite has been shown to yield remarkably robust Re-Os ages for the following reasons: (1) it typically incorporates Re in ppm concentrations and excludes $\mathrm{Os}$, thereby allowing common ${ }^{187} \mathrm{Os}$ to be ignored and all the ${ }^{187} \mathrm{O}$ s to be attributed to the in-situ decay of ${ }^{187} \mathrm{Re}$; (2) inheritance of older cores and overgrowths and chemical isotopic exchange are exceedingly rare; (3) the Re-Os system in molybdenite can withstand intense deformation and high-grade thermal metamorphism; (4) the closure temperature of the Re-Os isotope system in molybdenite is relatively high; and (5) neither Re nor Os are accommodated by silicate minerals, thereby ensuring that they remain in molybdenite (e.g., Stein et al., 1998, 2001, 2003; Selby and Creaser, 2001a, b, 2004; Selby et al., 2002, 2007; Lawley and Selby, 2012; Stein, 2014; Stein and Hannah, 2015 and references therein).

During the past decade, the implementation and improvement of the Re-Os and U-Pb methods and their use in combination with other chronometers has helped constrain the timing and duration of oreforming events with a high level of accuracy and precision (e.g., von Quadt et al., 2002, 2014, 2016; Chiaradia et al., 2009a, b, 2013, 2014; Zimmerman et al., 2014; Chelle-Michou et al., 2014, 2015b; Buret et al., 2017; Chang et al., 2017; Li Y et al., 2018; Cao et al., 2019). Porphyry Cu-Mo-(Au) deposits provide, by far, the best examples of the direct dating and bracketing of ore formation using the molybdenite Re-Os dating method because of the common occurrence of significant proportions of molybdenite in these deposits. The timing of intrusion-related $\mathrm{Sn}$ mineralization can also be determined directly using the cassiterite U-Pb method (Yuan et al., 2008, 2011). In contrast, the ages of other magmatichydrothermal ore deposits are still poorly constrained, and most of the ages that have been determined for these deposits (e.g., Au) are based on "indirect" isotopic methods, e.g., sericite $\mathrm{Ar}-\mathrm{Ar}$ and Rb-Sr, calcite Sm-Nd, and monazite U-Pb ages (Hart et al., 2002; Li et al., 2006, 2012; Su et al., 2009; Zhai et al., 2015; Li $X$ et al., 2019). However, these gangue minerals may not be coeval with gold deposition from the ore fluids, and/or the isotopic systems have been disturbed by post-ore events. Thus, interpretations based on their ages should be made with caution (Selby et al., 2002).

In this study, we test the reliability of a variety of chronometers in determining the age of the Haigou lode gold deposit, namely the molybdenite Re-Os, pyrite Re-Os, zircon U-Pb and sericite $\mathrm{Ar}-\mathrm{Ar}$ chronometers. We also discuss and decipher the important controls on the accuracy and reproducibility of the molybdenite Re-Os ages. Our new geochronological data, in combination with geological observations and a knowledge of the regional metallogeny, place important constraints on the genesis of the Haigou lode gold deposit in the context of the tectonic evolution of the Central Asian Orogenic Belt (CAOB). In so doing, they identify a previously unknown Paleozoic Au mineralization event along the suture between the $\mathrm{CAOB}$ and the North China Craton (NCC), and provide new insights into the evolution of one of China's most important gold mining districts. 


\section{Regional geology}

The Haigou lode gold deposit is located in the Jiapigou-Haigou gold belt in NE China (Fig. 1A, B), which is one of the most important gold-producing districts in China and was responsible for nearly half of China's gold production during the early 1960s (estimated Au reserves $>150$ t; Deng et al., 2009; Zeng et al., 2014). This belt lies on the boundary between the CAOB and the NCC (Fig. 1A).

The $\mathrm{CAOB}$ evolved through a complex closure of the Paleo-Asian Ocean from the Neoproterozoic to the late Phanerozoic (Wilde, 2015), which separated the Siberian Craton in the north from the Tarim and North China Cratons in the south (Fig. 1A). Microcontinental blocks, which are widely distributed in the $\mathrm{CAOB}$, have been proposed to have originated as part of Rodinia along the global Grenville Orogenic Belt between 1100 and $750 \mathrm{Ma}$ (Zhou et al., 2018). This region records the complex processes of tectonic events that marked the transition from the dominantly NE-SW directed motion of the PaleoAsian plate to the E-W directed motion of the Paleo-Pacific plate (e.g., Li, 2006; Wilde, 2015; Zhou et al., 2018; Liu et al., 2017 and references therein). There was an overlap in the Late Permian-Early Triassic between activity associated with the Paleo-Asian Ocean closure and the onset of tectonism related to Paleo-Pacific Ocean subduction, a switch in geodynamic setting which is interpreted to have occurred at 260-250 Ma (Zhou and Wilde, 2013; Wilde, 2015).

The evolution of the CAOB involved the accretion of numerous island-arcs at the margins of the NCC and the Siberian Craton during the Paleozoic (Fig. 1B; Sengör and Natal'in, 1996). It also has been shown that tectonic features within the NCC were reactivated by multiple Paleozoic to Mesozoic orogenic events along its margin, e.g., the closure of the Paleo-Asian Ocean during the Late Permian and continued convergence from the north that resulted in thrusting and significant crustal thickening on its northern margin (Xiao et al., 2003); these events continued into the Triassic in the eastern part of the suture (Wilde, 2015). The accreted marginal orogenic belts collided along the Solonker-Xar MoronChangchun-Yanji suture and represent the terminal closure event within the southeast Paleo-Asian Ocean (Sengör and Natal'in, 1996; Xiao et al., 2003; Wilde, 2015).

There are five major terranes in the Chinese portion of the eastern CAOB (Fig. 1B). These are, from west to east, the Erguna block, the Xing'an block, the Songliao block, a Paleozoic accretionary complex along the northern margin of the NCC known as the Liaoyuan Terrane, and the combined Jiamusi/Khanka block (which is linked to the Bureya block in Russia). The different units are separated by distinct sutures (Fig. 1B). The Erguna, Xing'an and Songliao blocks are commonly referred to as the Xing'an-Mongolian Orogenic Belt (ХMOB) in the Chinese literature (Wu et al., 2004; Xu et al., 2015). However, it is still unclear whether the combined Bureya-Jiamusi-Khanka block (Fig. 1B) is part of the CAOB or a separate crustal fragment that owes its location to Paleo-Pacific subduction (Wu et al., 2007; Zhou et al., 2010).

Paleozoic igneous rocks along the Solonker-Xar Moron-Changchun-Yanji suture are mainly Carboniferous to Permian in age, with the youngest arc-related rocks having formed during the Early Triassic, thereby providing compelling evidence for a Permian/Triassic closure of the Paleo-Asian Ocean (Xiao et al., 2003; Li, 2006; Liu et al., 2016; Eizenhöfer and Zhao, 2018 and references therein). The region was subsequently affected by tectonism associated with the westward subduction of the Paleo- 
144

145

146

147

148

149

150

151

152

153

154

155

156

157

158

159

160

161

162

163

164

165

166

167

168

169

170

171

172

173

174

175

176

177

178

179

180

181

Pacific plate in the Late Permian-Early Triassic (ca. 260-250 Ma). In the Early Cretaceous (ca. 140 Ma), the Paleo-Pacific plate retreated eastward, producing an extensional setting associated with regional thinning and delamination of the lithosphere in NE China (e.g., Li, 2006; Zhang et al., 2010; Wu et al., 2011; Wilde, 2015; Zhou et al., 2018; Liu et al., 2017). Paleozoic and Mesozoic granites are common in the Jiapigou-Haigou gold belt (Fig. 1C) as a result of multiple tectonic events. Consequently, most of the ore deposits in the region (e.g., porphyry Cu-Mo-Au deposits, Ag-Pb-Zn veins, and epithermal and orogenic Au deposits) are interpreted to be of Mesozoic age (Yang et al., 2003; Zeng et al., 2012; Mao et al., 2014; Ouyang et al., 2015; Shu et al., 2016; Chen et al., 2017; Gao et al., 2018; Zhai et al., 2014a, b, 2018a, b, c and references therein). Deposits of confirmed Paleozoic age are extremely rare (Yang et al., 2015; Gao et al., 2018; Yang and Cooke, 2019).

The regional faults (Mesoproterozoic to Mesozoic) include two groups, i.e., the NE- and NW-oriented fault or shear zones (Fig. 1C). The NE-oriented faults include the Dunhua fault, which is part of the regional Tanlu fault in eastern China, and the Liangjiang fault. Between these faults, there are several parallel NW-oriented faults and shear zones ( 100 km long and 1-3 km wide; Fig. 1C). These faults commonly crosscut the Paleozoic and Mesozoic granitic intrusions (Fig. 1C). The Jiapigou shear zones controlled the location of the Jiapigou gold belt, whereas the Haigou gold deposit occurs north of the Jinyinbie fault (Fig. 1C).

\section{Ore deposit geology}

The Haigou quartz veins are located in an area underlain by the Proterozoic Seluohe Complex (Fig. 2), which is composed mainly of gneiss, quartz-plagioclase-hornblende schist, amphibolite and metarhyolite. On the basis of whole-rock K-Ar and muscovite K-Ar age determinations, the Seluohe Complex is interpreted to have formed between 1654 and $1646 \mathrm{Ma}$ (JBGMR, 1988). However, most of the auriferous Haigou quartz veins are hosted by a granitic stock (Haigou stock), comprising a central monzogranite and a border monzonite (Fig. 2). The contact between them is gradational (Zhang et al., 2012). The stock has an outcrop area of $\sim 5 \mathrm{~km}^{2}$, and was initially interpreted to have been emplaced at 167-186 Ma based on a whole-rock K-Ar age determination (Jiao et al., 2008). A recent zircon U-Pb geochronological study has constrained the age of the granitic stock in the Carboniferous between $322.9 \pm 3.4$ and $320.3 \pm 3.5 \mathrm{Ma}$ (Zhang et al., 2012). There are two other intrusions in the area. A Mesozoic biotite granite pluton (Huangnihe pluton), which has been dated at $120 \mathrm{Ma}$ using the zircon $\mathrm{U}-\mathrm{Pb}$ chronometer, is located immediately to the west of the ore deposit (Fig. 2) (Zhang et al., 2012), and a diorite intrusion in the eastern part of the ore district was emplaced in the Cretaceous (124 Ma, zircon U-Pb, this study; Fig. 2). None of the above Mesozoic plutons hosts any gold. Numerous mafic to felsic dikes cut the Haigou stock (Fig. 2). Compositionally, they comprise diabase, andesite, granodiorite, and diorite porphyry (Fig. $3 \mathrm{~A}$ ). Most of the dikes crosscut auriferous quartz veins, and some were truncated by auriferous veins (e.g., diorite porphyry; Fig. 3A, B). Several studies have concluded that these dikes formed in the Cretaceous on the basis of zircon U-Pb ages between $132.4 \pm 1.5$ and $124.6 \pm 2.2 \mathrm{Ma}$ (e.g., Li X et al., 2012; Chang et al., 2013; Zeng et al., 2017). The distribution of the dikes and the Au-bearing quartz veins was controlled mainly by numerous NE-NNE-oriented faults and less so 
182

183

184

185

186

187

188

189

190

191

192

193

194

195

196

197

198

199

200

201

202

203

204

205

206

207

208

by NS- and EW-oriented faults (Fig. 2). The southern part of the ore district was controlled by an EWoriented fault zone (Jinyinbie fault, Fig. 2), which is part of a regional fault system (Fig. 1B).

The Haigou deposit was discovered in 1965 and has been mined since 1984. Fifteen auriferous quartz veins have been identified in the monzogranitic stock and gneiss. These veins extend vertically up to $800 \mathrm{~m}$, and their lengths and widths vary from $\sim 100$ to $\sim 1000 \mathrm{~m}$ and $\sim 1$ to $\sim 20 \mathrm{~m}$ (Figs. 2 and 3), respectively. Reserves of more than $40 \mathrm{t}$ Au with an average grade of $3.4 \mathrm{~g} / \mathrm{t}$ have been identified (Zeng et al., 2017). The auriferous quartz veins occur in three clusters, namely, the V38, V28 and V43 clusters in the eastern, central and western parts of the ore district, respectively. The V28 cluster is the most important, and hosts $\sim 30 \mathrm{t}$ gold with grades from 3 to $10 \mathrm{~g} / \mathrm{t}$ (average of $8 \mathrm{~g} / \mathrm{t}$ ) (Zeng et al., 2017). This ore cluster consists of several continuous and parallel veins, which generally strike $N E\left(45^{\circ}\right)$ and dip NW $\left(312^{\circ}-318^{\circ}\right)$ at angles of $45^{\circ}-85^{\circ}$. The veins are $1000 \mathrm{~m}$ long and have widths of 0.2-17.7 $\mathrm{m}$ (average of $3.9 \mathrm{~m}$ ). They commonly extend vertically over intervals of up to $500 \mathrm{~m}$. The V38 ore cluster contains 6 t of gold reserves grading from 3 to $5 \mathrm{~g} / \mathrm{t}$ Au and the veins in this cluster strike NE and dip NW $\left(312^{\circ}\right)$ at angles of $30^{\circ}$ to $45^{\circ}$. They are generally about $500 \mathrm{~m}$ in length, have widths of 0.3 to $20 \mathrm{~m}$, and extend $>200$ m vertically. Minor disseminated Au mineralization occurs along the margins of the major veins.

Hydrothermal alteration is widespread, with the most intense alteration usually occurring in and around the mineralized quartz veins (Fig. 3C, D). The main alteration minerals are quartz, K-feldspar, sericite, chlorite, epidote, kaolinite and calcite. Alteration halos are distributed asymmetrically and discontinuously on either side of the mineralized veins (they are typically wider on the hanging wall side, e.g., 3-5 m) and are widest around the thickest veins. Silicic and potassic alteration were early and widespread. These alteration facies were overprinted by an assemblage of quartz, pyrite, sericite, and epidote. An assemblage of quartz, sericite, chlorite, and kaolinite overprinted the preceding alteration and was closely associated with abundant gold and sulfide mineral deposition. Finally, several calcitequartz veins and veinlets crosscut the altered rocks. There is no apparent spatial zonation of alteration types regionally as, in most cases, alteration assemblages were superimposed on one another. However, the alteration varies with the nature of the host rocks, e.g., early K-feldspar-quartz alteration in monzonite (Fig. 3C) is accompanied by early pyrite-sericite-quartz alteration in gneiss (Fig. 3D).

\section{Sampling and analytical methods}

\section{Mineral identification and molybdenite characterization}

Representative samples were collected from different mining levels accessible via ongoing underground mine development, and from drill holes. The gold-bearing samples were collected from variable depths. Well-polished thin sections were examined in reflected and transmitted light. Mineral compositions were determined using a JEOL 8230 Superprobe equipped with wavelength- and energydispersive X-ray detectors and a back-scatter electron detector at the Chinese Academy of Geological Sciences (CAGS). The rhenium concentrations in fine-grained molybdenite (5-20 $\mu \mathrm{m})$ were determined using a Cameca SX FIVE FE microprobe equipped with energy- and wavelength-dispersive spectrometers at the Department of Earth and Planetary Sciences, McGill University. The operating conditions were an 
acceleration voltage of $20 \mathrm{kV}$, a beam current of $20 \mathrm{nA}$, and a counting time of $200 \mathrm{~s}$ for Re. The beam diameter was $5 \mu \mathrm{m}$. The standard used was Re metal and the detection limit for Re was $50 \mathrm{ppm}$. A field emission scanning electron microscope (FESEM), a Zeiss Supra 55 Sapphire, at the China University of Geosciences Beijing (CUGB) was used to image ore textures and determine mineral compositions semiquantitatively for the purpose of identification. The accelerating voltage was $20 \mathrm{kV}$ and the working distance $15 \mathrm{~mm}$.

\section{In-situ LA-ICP-MS trace element analysis of molybdenite}

In-situ trace element analyses of relatively coarse-grained molybdenite (50 to $>300 \mu \mathrm{m}$ ) were conducted using LA-ICP-MS at the Wuhan SampleSolution Analytical Technology Co., Ltd., China. The analytical method for these analyses is based on that described in Ciobanu et al. (2013). A GeolasPro laser ablation system consisting of a COMPexPro $102 \mathrm{ArF}$ excimer laser (wavelength of $193 \mathrm{~nm}$ and maximum energy of $200 \mathrm{~mJ}$ ) was employed in conjunction with a MicroLas optical system. An Agilent 7700e ICP-MS instrument was used to acquire the ion signals. Helium was used as a carrier gas and argon as the make-up gas. The spot diameter and frequency of the laser were set to $32 \mu \mathrm{m}$ and $10 \mathrm{~Hz}$, respectively. Trace element compositions were calibrated using the reference standards, NIST-610 and MASS-1. An internal molybdenum standard was also used for calibration. Each analysis involved a background acquisition of approximately 20-30 s followed by $50 \mathrm{~s}$ of data acquisition from the sample.

An Excel-based program ICPMSDataCal was used to perform off-line selection and integration of background and analyzed signals, time-drift correction and quantitative calibration (Liu et al., 2008).

\section{$\mathrm{U}-\mathrm{Pb}$ dating of zircon}

Nine samples of unaltered igneous rocks (comprising samples from six dikes and three larger intrusions, including the Haigou granitic stock and the diorite intrusion) were collected from different mining levels and drill-core, based on their crosscutting relationships with auriferous quartz veins. Two samples (monzogranite and monzonite) from the stock hosting the deposit, and a sample from a diorite intrusion that does not host auriferous veins but intruded the stock in the eastern part of the ore district were analyzed to represent the larger intrusions. The numerous mafic to felsic dikes were carefully described with respect to their chronological relationships with the ore veins. They include a diorite porphyry dike (pre-ore) that is crosscut by ore veins, an unaltered and unmineralized andesite dike, which is parallel to an ore vein and may therefore have formed synchronously with mineralization, and a diabase dike that truncates veins and therefore post-dated the ores.

Zircon crystals in the intrusions/dikes were separated by standard heavy-liquid and magnetic techniques, and further purified by hand-picking under a binocular microscope. Prior to LA-ICP-MS analysis, the zircon crystals were imaged by cathodoluminescence $(\mathrm{CL})$ using a FESEM. The U-Pb dating of the zircon was carried out using a LA-ICP-MS in the State Key Laboratory of Geological Processes and Mineral Resources at CUGB. The crystals were ablated using an excimer laser ablation system (UP193SS) and an Agilent 7500a ICP-MS instrument was used to acquire the ion signals. A laser spot diameter of $36 \mu \mathrm{m}$, a laser energy density of $8.5 \mathrm{~J} / \mathrm{cm}^{2}$ and a repetition rate of $10 \mathrm{~Hz}$ were used during the analyses. Helium and argon were used as the carrier and make-up gases, respectively, and were mixed via a Tconnector before entering the ICP. Uranium, Th and $\mathrm{Pb}$ concentrations were calibrated by using ${ }^{29} \mathrm{Si}$ as 
an internal standard and the NIST 610 glass as the reference standard. The ${ }^{207} \mathrm{~Pb} /{ }^{206} \mathrm{~Pb},{ }^{206} \mathrm{~Pb} /{ }^{238} \mathrm{U}$, ${ }^{207} \mathrm{~Pb} /{ }^{235} \mathrm{U}$ and ${ }^{208} \mathrm{~Pb} /{ }^{232} \mathrm{Th}$ ratios were corrected for both instrumental mass bias and depth-dependent elemental and isotopic fractionation using Harvard zircon 91500 as the external standard (Wiedenbeck et al., 1995). The zircon standard, TEMORA, was used as a secondary standard to monitor the deviation of the age measurement (Black et al., 2003). Isoplot 3.0 was used to calculate the ages and make concordia plots (Ludwig, 2003). The data obtained for the Harvard zircon 91500 and TEMORA zircon standards yielded weighted mean ages of $1062.5 \pm 0.5$ and $418.0 \pm 6.9 \mathrm{Ma}$, respectively, which are very similar to the reported ages (1065 and $417 \mathrm{Ma}$, respectively; Wiedenbeck et al., 1995; Black et al., 2003).

\section{Re-Os dating of molybdenite and pyrite}

A total of 6 molybdenite- and 11 pyrite-bearing auriferous quartz vein samples was collected. The molybdenite-bearing samples are from the lower part of the deposit (>500 $\mathrm{m}$ depth), whereas the pyrite-bearing samples were taken from a variety of depth intervals. Molybdenite occurs either as small veins or veinlets in the auriferous veins (commonly 0.3-5 $\mathrm{mm}$ in thickness) (Fig. 4A), or as very fine coatings ( $<0.1$ to $0.2 \mathrm{~mm}$ thick) on the walls of quartz veins immediately adjacent to the host granitic stock in association with potassic and sericitic alteration assemblages (Fig. 4B). In several locations, the occurrences of molybdenite on vein margins have been partially sheared due to post-ore deformation. The molybdenite is associated locally with pyrite in potassically-altered quartz veins (Fig. 4C). Pyrite commonly occurs as mineral aggregates in auriferous quartz veins. To deal with the possible mobilization of minor radiogenic ${ }^{187}$ Os from molybdenite into the adjacent pyrite (Stein et al., 2003), the pyrite samples were collected from sites that were far-removed from the molybdenite. The grain size of the molybdenite in the samples either is very fine (i.e., $<10$ to $200 \mu \mathrm{m}$ ), or relatively coarse (i.e., 0.3 to $5 \mathrm{~mm}$ ). The diameter of pyrite grains generally varies from 1 to $5 \mathrm{~mm}$.

The sample preparation and mineral separation were performed using the methodology recommended by Du et al. (1995), Stein et al. (2003) and Selby and Creaser (2004). In brief, clean mineral separates of molybdenite and pyrite were obtained using traditional isolation methods (e.g., crushing, magnetic, and/or heavy liquid separation), and were further handpicked under a binocular microscope. Individual samples of 200 to $300 \mathrm{mg}$ were checked for homogeneity by multiple analyses of the mineral separates obtained using the material prepared with the different sampling procedures, i.e., "bulk sampling" and multiple mineral separates split from one sample (e.g., Stein et al., 1998, 2001; Selby and Creaser, 2001a, 2004; Li Y et al., 2017). In addition, a total of six model ages were determined for fine-grained molybdenite at four locations along a traverse across a single sample (HG-32); the distance between adjacent locations was less than $1 \mathrm{~cm}$ (Fig. 4B).

The analyses were carried out in three laboratories; the Laboratory for Sulfide and Source Rock Geochronology and Geochemistry at Durham University (DU), United Kingdom, the Re-Os Laboratory at the National Research Center of Geoanalysis (CAGS), China, and the State Key Laboratory of Ore Deposit Geochemistry, Institute of Geochemistry, Chinese Academy of Sciences (IGCAS). All mineral separates, with the exception of those performed at Durham, were carried out at CUGB. The analytical procedures for determining the rhenium and osmium contents and their isotopic compositions in the molybdenite and pyrite mineral separates were those recommended by Du et al. (2004), Qi et al. (2010) 
and Lawley and Selby (2012) and references therein. The Carius tube method was used for the dissolution of the molybdenite and equilibration of the samples with a Re and Os tracer solution (Selby and Creaser, 2001a). Molybdenite was dissolved and equilibrated with ${ }^{185} \mathrm{Re}$ and ${ }^{190} \mathrm{Os}$ spike solutions at CAGS and IGCAS, and with a mixed ${ }^{185} \mathrm{Re}+{ }^{190} \mathrm{Os}$ spike with a normal isotope composition at DU. Pyrite was dissolved with approximate inverse aqua regia and known amounts of ${ }^{185} \mathrm{Re}$ and ${ }^{190} \mathrm{Os}$ spikes. The Re-Os isotopic data for molybdenite were obtained using isotope dilution negative thermal ionization mass spectrometry (ID-N-TIMS, Creaser et al., 1991; Völkening et al., 1991) at DU in the Arthur Holmes Laboratory, and isotope dilution ICP-MS at CAGS (TJA PQ ExCell) and IGCAS (PE ELAN DRC-e). The ReOs isotopic analysis for pyrite was carried out at CAGS and IGCAS using isotope dilution ICP-MS. The uncertainties in the Re and Os isotope composition measurements, tracer calibration, sample and tracer weighing, reproducibility of Re and Os isotope standards, blank abundances and isotopic compositions were all propagated. The blanks were $<3 \mathrm{pg}$ for Re and $<0.5 \mathrm{pg}$ for ${ }^{187} \mathrm{Os}$ for measurements at DU, and were $<10 \mathrm{pg}$ for Re and $<2 \mathrm{pg}$ for ${ }^{187} \mathrm{Os}$ at CAGS and IGCAS. In order to evaluate the accuracy and reproducibility of the analyses, the reference materials, Henderson molybdenite (RM8599, $27.66 \pm$ $0.10 \mathrm{Ma}$, Markey et al., 2007; Zimmerman et al., 2014), JDC (139.6 $\pm 3.8 \mathrm{Ma}$, Du et al., 2004), and HLP (221.4 $\pm 5.6 \mathrm{Ma}$, Du et al., 2004) were run during the course of this study; the model ages obtained were $27.695 \pm 0.038 \mathrm{Ma}$ ( $n=9$, DU; Li et al., 2017a), $140.1 \pm 2.8 \mathrm{Ma}$ ( $n=6$, CAGS; Zhai et al., 2017), and $223.0 \pm 2.4 \mathrm{Ma}(\mathrm{n}=5$, IGCAS; Huang et al., 2013), respectively. The molybdenite Re-Os age was calculated using a ${ }^{187}$ Re decay constant of $1.666 \times 10^{-11} y^{-1}$ with an uncertainty of $0.31 \%$ (Smoliar et al., 1996; Selby et al., 2007). Isoplot 3.0 was used to calculate the isochron ages (Ludwig, 2003).

\section{Ar-Ar dating of sericite}

A sericite sample was collected from a pyrite-sericite-altered auriferous quartz vein ( $\sim \mathrm{m}$ in width) hosted by monzonite from the underground mine. The sericite-altered auriferous vein was cut, crushed, washed and then handpicked to obtain sericite grains, which were irradiated together with the ZBH- 25 biotite standard (132.7 $\pm 1.2 \mathrm{Ma}$ at $1 \sigma$; Wang, 1983) for $55 \mathrm{~h}$ in the Swimming Pool Reactor, Chinese Institute of Atomic Energy (Beijing). After three months of cooling, the sample was analyzed using the ${ }^{40} \mathrm{Ar} /{ }^{39} \mathrm{Ar}$ stepwise incremental heating method and a MM-1200B mass spectrometer at the Institute of Geology, CAGS. Details of the method were reported by Chen et al. (2006). Measured isotopic ratios were corrected for mass discrimination, atmospheric argon, blanks and irradiationinduced mass interference. Correction factors for the interfering isotopes during irradiation were determined by an analysis of pure irradiated $\mathrm{K}_{2} \mathrm{SO}_{4}$ and $\mathrm{CaF}_{2}$ having values of $\left({ }^{36} \mathrm{Ar} /{ }^{37} \mathrm{Ar}\right)_{\mathrm{Ca}}=0.0002389$, $\left({ }^{40} \mathrm{Ar} /{ }^{39} \mathrm{Ar}\right)_{\mathrm{K}}=0.004782$ and $\left({ }^{39} \mathrm{Ar} /{ }^{37} \mathrm{Ar}\right) \mathrm{ca}_{\mathrm{a}}=0.000806$. The ${ }^{40} \mathrm{~K}$ decay constant used was the value of $5.543 \times 10^{-10}$ year $^{-1}$ recommended by Steiger and Jäger (1977). The age uncertainties with decay uncertainty are reported at the $95 \%$ confidence level $(2 \sigma)$ and the Ar-Ar age was calculated using Isoplot 3.0 (Ludwig, 2003).

\section{Results}

\section{Ore paragenesis and gold occurrence}

Four primary paragenetic stages (I to IV) were identified in the Haigou Au deposit, based on the 
nature of the mineralization and the mineral assemblages (Fig. 5). Stage III is the most important stage for Au deposition. The gold typically occurs as the native metal with $<10 \mathrm{wt} \% \mathrm{Ag}$, and commonly coexists with galena embedded in early-formed pyrite (Fig. 6A). Native gold also occurs as isolated grains in quartz (Fig. 6B), which were observed to coexist with minor tellurides (i.e., altaite, coloradoite, and hessite; Figs. 6B and 7). Locally, the gold is present as small grains within or adjacent to molybdenite platelets (Fig. 6C-F), suggesting that the two phases formed coevally. The co-deposition of native gold and molybdenite enables the gold mineralization to be dated directly using the molybdenite Re-Os chronometer.

\section{The Re distribution in molybdenite}

The Re concentrations in fine- and coarse-grained molybdenite determined using the electron microprobe and in-situ LA-ICP-MS are reported in the Supplementary data (Tables A1 and A2), and some of the results are illustrated in Figure 8 . The electron microprobe data show that the $\operatorname{Re}$ concentrations of different fine-grained molybdenite crystals in a single sample vary widely, i.e., from 79 to 468 ppm (all the values are above the detection limit for Re) (Table A1 and Fig. 8A). The in-situ LA-ICP-MS spot analyses of the coarse-grained molybdenite crystals and their veins also demonstrate a heterogeneous distribution of Re concentration with a range of 49-210 ppm (Table A2, Fig. 8B-D).

\section{Zircon U-Pb geochronology}

Numerous zircon U-Pb age determinations have been carried out for the different intrusive rocks in the ore district. These are reported in the Supplementary data (Table A3) and are summarized here. The monzogranite and monzonite that host the ore have mean ${ }^{206} \mathrm{~Pb} /{ }^{238} \mathrm{U}$ ages of 327.1 $\pm 1.1 \mathrm{Ma}(\mathrm{N}=20, \mathrm{MSWD}=0.75)$ and $329.5 \pm 1.0 \mathrm{Ma}(\mathrm{N}=19, \mathrm{MSWD}=0.18)(\mathrm{Fig} .9 \mathrm{H}, \mathrm{l})$, respectively, showing that the stock crystalized in the Late Paleozoic. In contrast, the diorite intrusion in the eastern part of the ore district yielded a mean ${ }^{206} \mathrm{~Pb} /{ }^{238} \mathrm{U}$ age of $128.4 \pm 0.3 \mathrm{Ma}(\mathrm{N}=15, \mathrm{MSWD}=0.78)$ (Fig. 9G). A diorite porphyry dike, which was cut by auriferous quartz veins (Fig. 9A), yielded a mean ${ }^{206} \mathrm{~Pb} /{ }^{238} \mathrm{U}$ age of $318.3 \pm 1.0 \mathrm{Ma}(\mathrm{N}=25, \mathrm{MSWD}=0.19)$. In contrast, an andesite dike, which is oriented parallel to gold-bearing quartz veins and was free of evidence of alteration and mineralization (Fig. 9B), was dated at $310.9 \pm 1.1 \mathrm{Ma}(\mathrm{N}=15, \mathrm{MSWD}=0.29)$. However, a similar andesite dike which was collected from a site at lower elevation, and is also oriented parallel to the ore veins, yielded a mean ${ }^{206} \mathrm{~Pb} /{ }^{238} \mathrm{U}$ age of $2446.5 \pm 9.0 \mathrm{Ma}(\mathrm{N}=23, \mathrm{MSWD}=0.19)$ (Fig. 9D), providing clear evidence that the analyzed zircon crystals were all inherited from the Proterozoic protolith. A diabase dike, which cut the orebodies (Fig. 9C), has a mean ${ }^{206} \mathrm{~Pb} /{ }^{238} \mathrm{U}$ age of $134.9 \pm 0.4 \mathrm{Ma}(\mathrm{N}=19$, MSWD = 0.27), whereas a diorite porphyry dike, which also crosscut the orebodies yielded a mean ${ }^{206} \mathrm{~Pb} /{ }^{238} \mathrm{U}$ age of $340.3 \pm 1.9 \mathrm{Ma}(\mathrm{N}=16, \mathrm{MSWD}=0.79$ ) (Fig. 9F). As this age is greater than that of the intrusions hosting the deposit, we conclude that all of the analyzed zircon crystals were inherited from older rocks. Finally, a granodiorite dike from the ore district has a mean zircon ${ }^{206} \mathrm{~Pb} /{ }^{238} \mathrm{U}$ age of $259.8 \pm 0.4 \mathrm{Ma}(\mathrm{N}=46, \mathrm{MSWD}=2.0$ ) (Fig. 9E). The data presented above therefore bracket the age of gold mineralization between 318.3 and $134.9 \mathrm{Ma}$, although the results for the andesite dike that was emplaced parallel to the quartz veins may indicate an age of gold mineralization closer to the former. 


\section{Molybdenite/pyrite Re-Os geochronology}

The total Re concentration of the molybdenite samples ranges from 0.02 to 142.8 ppm (19 analyses of 6 samples; Table 1). Only two analyses of multiple mineral separates from one sample yielded very low Re contents (0.02 and $0.21 \mathrm{ppm}$, sample HG-34); the other 17 analyses returned Re concentrations ranging from 8.0 to $142.8 \mathrm{ppm}$ (average in $78.8 \mathrm{ppm}$ ). As is the case for the Re contents, the model ages for the molybdenite also vary considerably, i.e., from $467.1 \pm 41.0$ to $155.3 \pm 1.8 \mathrm{Ma}$ (Table 1). The ages determined at DU using N-TIMS range from $345.6 \pm 19.9$ to $306.7 \pm 1.2 \mathrm{Ma}$, and those determined at CAGS and IGCAS using ICP-MS range from 467.1 \pm 41.0 to $155.3 \pm 1.8 \mathrm{Ma}$ and $314.6 \pm 6.2$ to $298.7 \pm 2.4 \mathrm{Ma}$, respectively. After excluding one extremely old $(467.1 \pm 41.0 \mathrm{Ma})$ and two very young $(193.5 \pm 2.2$ and $155.3 \pm 1.8 \mathrm{Ma})$ model ages, the data for the remaining sixteen molybdenite samples yield a weighted mean age of 314.6 $\pm 5.0 \mathrm{Ma}$ (Fig. 10A) and an isochron age of $304.8 \pm 7.6 \mathrm{Ma}$ (Fig. 10B). Nine of these 16 samples returned similar model ages of $318.2 \pm 3.9$ to 305.8 \pm 5.7 Ma and a weighted mean age of 310.0 $\pm 2.6 \mathrm{Ma}(\mathrm{MSWD}=12$ ) (Fig. 10C), which, within uncertainty, is the same as the ${ }^{187} \mathrm{Re}^{187} \mathrm{Os}$ isochron age of $308.6 \pm 8.1 \mathrm{Ma}$ (MSWD =9) (Fig. 10D).

The total Re and Os concentrations in the pyrite vary from 0.25 to $2372.43 \mathrm{ppb}$ and 1.64 to 7825.12 ppt, respectively $(n=13)$. The ${ }^{187} \operatorname{Re} /{ }^{188}$ Os ratios range from $\sim 600000$ to $\sim 1000$, with the majority of the samples returning values greater than $5000\left(n=9\right.$, Table A4). The extremely high ${ }^{187} \mathrm{Re} /{ }^{188} \mathrm{Os}$ ratios classify the bulk of the sulfide samples as being Low Level Highly Radiogenic (LLHR; Stein et al., 2000; Selby et al., 2009), and this is reflected in the low common Os values (Table A4). The ${ }^{187}$ Os/ ${ }^{188}$ Os ratios vary from $\sim 10$ to $\sim 3000$ with the majority of the samples yielding values greater than 30 ( $n=8$, Table A4). Given the relatively high Re concentrations in some of the samples ( 2.4 ppm in HG-47-b, Table A4) and their high Re/Os, it is very likely that much of the Re is not crystallographically contained within the pyrite structure. Instead, this Re and Os may have originated from micro- to nano-scale molybdenite inclusions hosted in the bulk analyzed pyrite, despite careful sampling and micro-scale observations designed to exclude them from Re-Os analysis. The 13 pyrite analyses collectively yield an isochron age of $319.7 \pm 6.2 \mathrm{Ma}$, which overlaps with the age of molybdenite. However, the initial ${ }^{187} \mathrm{Os} /{ }^{188} \mathrm{Os}$ ratio from the best fit is strongly negative and the associated error is very large $(-6 \pm 17$; Fig. A1). Moreover, the best fit is largely controlled by one sample (HG-27) and the scatter about the best fit is considerable (MSWD $=\sim 2000$ ), indicating that the data do not meet the requirements necessary to return a meaningful isochron age.

\section{Sericite Ar-Ar geochronology}

The ${ }^{40} \mathrm{Ar} /{ }^{39} \mathrm{Ar}$ data for sericite from a pyrite-sericite-altered auriferous quartz vein are reported in Supplementary data (Table A5), and the apparent age spectra and isochron diagram are illustrated in Figure 11. The plateau age is $165.3 \pm 1.2 \mathrm{Ma}(\mathrm{MSWD}=0.19$, Fig. $11 \mathrm{~A}$ ), and the inverse isochron age is $166.0 \pm 1.6 \mathrm{Ma}$ (MSWD = 3.9, Fig. 11B), which are the same within the analytical uncertainty. The plateau age is defined by seven continuous heating steps corresponding to $75.4 \%$ of the total ${ }^{39} \mathrm{Ar}$ released. The initial ${ }^{40} \mathrm{Ar} /{ }^{36} \mathrm{Ar}$ ratio of $284 \pm 14$ is indistinguishable from the atmospheric value. 


\section{The Re-Os geochronology}

415

416

417

418

419

420

421

422

423

424

425

426

427

428

429

430

431

432

433

434

435

436

437

438

439

440

441

442

443

444

445

446

447

448

449

450

Although we were able to reliably determine the age of the Haigou gold mineralization using the molybdenite Re-Os geochronometer, several of the samples yielded anomalously old or young ages. Significantly, the fine-grained molybdenite separates returned geologically meaningful ages, whereas the coarse-grained samples commonly yielded anomalously old or young model ages.

The ages for the fine-grained molybdenite samples (i.e., HG-30, 31, 32 and 33; Table 1), involving both replicate analyses of the same aliquot and multiple measurements of different mineral separates, are commonly close to the calculated weighted mean model age of $314.6 \pm 5.0 \mathrm{Ma}$ ( $n=16$; including analyses from DU, CAGS and IGCAS). Several model ages for a single sample also suggest that, except in one case, the model ages of fine-grained molybdenite are very similar ( $305.8 \pm 5.7$ to $311.3 \pm 3.9 \mathrm{Ma}$ ); the remaining model age is $155.3 \pm 1.8 \mathrm{Ma}$ (Fig. 4B). It should be noted, however, that the mass of molybdenite analyzed from this location was very small, the smallest for all the samples analyzed (2 $\mathrm{mg}$ ). Another sample from this location returned a model age of $311.3 \pm 3.9 \mathrm{Ma}$ (the sample weight was $6 \mathrm{mg}$ ). Consequently, the anomalously young model age for the fine-grained samples is attributed to the small aliquot of material used for analysis (cf. Stein et al., 2001, 2003; Selby et al., 2003, 2004; Selby and Creaser, 2004). In contrast, the coarse-grained molybdenite samples (i.e., HAIG-23 and HG-34) all yielded ages (mostly older) that are inconsistent with the geology of the deposit (Table 1). It should be noted that the three samples of coarse-grained molybdenite, which returned highly anomalous ages were small (HG-34-b - 467.1 Ma with 5 mg and HAIG-23 - 347.6 and $193.5 \mathrm{Ma}$ with 5 and $6 \mathrm{mg}$, respectively). In summary, all molybdenite samples weighing more than $15 \mathrm{mg}$ yielded reliable Re-Os ages (Fig. 12, Table 1).

Although the isochron and weighted mean model ages of molybdenite samples in the deposit were well constrained (Fig. 10C, D), replicate determinations of the age of the same aliquot (e.g., HG-32-d1 and d2, weighing $20 \mathrm{mg} ; 306.7 \pm 1.2$ and $310.2 \pm 1.3 \mathrm{Ma}$, respectively, Table 1 and Fig. 4B) and multiple analyses of different aliquots from the same sample (e.g., HG-33-a and b of $314.0 \pm 1.3$ and $307.5 \pm 1.8$ Ma weighing $>15 \mathrm{mg}$, Table 1 ) were not strictly reproducible within the analytical uncertainty. A likely explanation for this and some of the anomalous ages is spatial decoupling of daughter ${ }^{187}$ Os from parent ${ }^{187}$ Re within single crystals, a phenomenon that increases in importance with increasing grain size (Stein et al., 2001, 2003; Selby and Creaser, 2004; Porter and Selby, 2010). Alternatively, some of the molybdenite may have been deformed after crystallization, creating dislocations or defects into which ${ }^{187}$ Os could preferentially accumulate (Stein et al., 2003; Selby and Creaser, 2004). Therefore, the ReOs data obtained for molybdenite in a shear plane/vein (Fig. 4B), which was active over a period of several million years (e.g., 311 to $306 \mathrm{Ma}$ ), could be meaningful. The hypothesis of decoupling between

${ }^{187}$ Os and ${ }^{187} \mathrm{Re}$, however, is supported by the observation that within single molybdenite crystals, the Re content varies considerably, e.g., from 49 to 101 ppm in a single crystal from sample HG-32 (Fig. 8B, Table A2). The reason for the heterogeneous distribution of $\mathrm{Re}$ in the molybdenite of these samples is still unclear but may be related to the overall abundance of Re in the hydrothermal fluid (Rathkopf et 
451

452

453

454

455

456

457

458

459

460

461

462

463

464

465

466

467

468

469

470

471

472

473

474

475

476

477

478

479

480

481

482

483

484

485

486

487

488

489

al., 2017), compositional changes in the hydrothermal fluid with time (Stein et al., 2001), or partitioning of Re between vapor and liquid (Stein, 2014); analogous behavior has been reported for Mo (Hurtig and Williams-Jones, 2014; Williams-Jones and Migdisov, 2014), and/or the post-ore deformation of the molybdenite.

As reported above, a total of 13 pyrite separates free of molybdenite that could be detected using a scanning electron microscope, were analyzed for the purpose of Re-Os geochronology. Because some of these samples had high Re contents and high Re/Os ratios, we conclude that they likely contained nano-particles of molybdenite that could not be observed. Moreover, although the 13 samples yielded an isochron date of $319.7 \pm 6.2 \mathrm{Ma}$, which overlaps with the age of molybdenite, the initial ${ }^{187} \mathrm{Os} /{ }^{188} \mathrm{O}$ s ratio predicted by this isochron is strongly negative. We therefore conclude that pyrite Re-Os chronometer could not be used to determine the age of the gold mineralization and do not consider this chronometer further.

\section{A previously unrecognized Paleozoic gold mineralization}

The vast majority of the magmatic-hydrothermal ore deposits in the eastern CAOB formed between the Jurassic and Cretaceous (i.e., 160 to 120 Ma; Mao et al., 2014; Ouyang et al., 2015; Gao et al., 2018). However, very few ages have been reported for the lode gold deposits in this region and the only ages that are available are consistent with a Mesozoic age for this mineralization; these ages were determined mainly from sericite associated with the gold mineralization using the Ar-Ar method (e.g., Hart et al., 2002; Yang et al., 2003; Yu et al., 2010; Chai et al., 2016). Thus, most researchers consider the lode gold deposits in this region to be genetically related to Mesozoic granites emplaced during Paleo-Pacific oceanic plate subduction (e.g., Yang et al., 2003; Yu et al., 2010). This includes the Haigou gold deposit, which is the focus of the current study (e.g., Yu et al., 2010; Li L et al., 2017; Zeng et al., 2017). Li L et al. (2017) proposed an age of $161.9 \pm 1.3 \mathrm{Ma}$ for the Haigou deposit based on Ar-Ar dating of associated sericite, and Yu et al. (2010) and Feng (1998) obtained ages of $171 \pm 16 \mathrm{Ma}$ and $144 \mathrm{Ma}$, respectively, for fluid inclusions in auriferous quartz veins using Ar-Ar and K-Ar methods. Finally, several studies have concluded that the gold mineralization at Haigou took place between 132 and $125 \mathrm{Ma}$, based on zircon U-Pb age determinations for dikes that crosscut the orebodies (e.g., Li X et al., 2012; Chang et al., 2013; Zeng et al., 2017). However, the zircon U-Pb ages for the dikes cutting orebodies can only establish the lower age limit for gold deposition at Haigou and not the actual timing of gold mineralization.

Our new Re-Os and U-Pb geochronological results indicate that the gold mineralization at Haigou is much older than previously thought and took place in the Late Paleozoic. The granitic stock, which hosts the auriferous quartz veins, yielded mean zircon ${ }^{206} \mathrm{~Pb} /{ }^{238} \mathrm{U}$ ages between $327.1 \pm 1.1$ and 329.5 $\pm 1.0 \mathrm{Ma}$ (Fig. $9 \mathrm{H}, \mathrm{I}$ ), consistent with its emplacement during the Late Paleozoic. The molybdenite, which is closely associated with gold in the deposit (Fig. 6C-F), yielded a weighted mean Re-Os age of $310.0 \pm 2.6 \mathrm{Ma}(\mathrm{n}=9, \mathrm{MSWD}=12$; Fig. $10 \mathrm{C})$, and a well-constrained ${ }^{187} \mathrm{Re}^{-187} \mathrm{Os}$ isochron age of $308.6 \pm 8.1 \mathrm{Ma}$ (MSWD =9; Fig. 10D). Significantly, this age is the same as that of a dike (mean ${ }^{206} \mathrm{~Pb} /{ }^{238} \mathrm{U}$ zircon model age of $310.9 \pm 1.1 \mathrm{Ma}$; Fig. 9B), which, based on its orientation parallel to the 
490

491

492

493

494

495

496

497

498

499

500

501

502

503

504

505

506

507

508

509

510

511

512

513

514

515

516

517

518

519

520

521

522

523

524

525

526

527

528

auriferous veins, we speculate may have been emplaced contemporaneously with the ore. In summary, we conclude from the Re-Os ages of molybdenite closely associated with native gold in quartz veins and a similar $\mathrm{U}-\mathrm{Pb}$ zircon age for a possible syn-ore dike that the Haigou gold deposit formed at $310 \mathrm{Ma}$ (Fig. 13).

The discovery that the Haigou gold deposit, one of the largest in the region, is of Late Paleozoic age and not Late Mesozoic age, as previously proposed, raises considerable doubt over the conclusion that the gold deposits in the region all formed in the Late Mesozoic (ca. 160-120 Ma, e.g., Hart et al., 2002; Yang et al., 2003; Zeng et al., 2012; Mao et al., 2014; Ouyang et al., 2015; Zhai et al., 2015; Chen et al., 2017; Gao et al., 2018 and references therein). It also raises doubts about the appropriateness of using the Ar-Ar method to date these deposits (most of the gold deposits in the region have been dated using this method), because of the ease with which these dates can be reset by later thermal events. Indeed, our own analysis of sericite from an auriferous vein in the Haigou deposit exemplifies the problem nicely. Although the analysis yielded a very convincing plateau age of $165.3 \pm 1.2 \mathrm{Ma}$ (Fig. 11a), the Re-Os and U-Pb data demonstrate very clearly that this represents an age that was reset during the emplacement of Late Mesozoic intrusions (mostly in the western part of the ore district; Fig. 2) and dikes (Figs. 2 and 3). Two previous studies (e.g., Yu et al., 2010; Li L et al., 2017) for the Haigou deposit also demonstrated that the Ar-Ar ages have been largely reset by the post-ore magmatic events. Thus, sericite Ar-Ar ages should be interpreted with caution, if there was post-ore magmatism in the region. Our new geochronological data, by showing that the gold mineralization is of Late Paleozoic age, emphasize the need for careful geochronological studies to evaluate the true timing of gold mineralization in relatively complex geologic settings.

\section{The tectonic setting of the Haigou Paleozoic gold mineralization}

Northeastern China and adjacent regions belong to the Paleozoic accretionary margins of the Siberia Craton and the NCC (Wang et al., 2016; Yang et al., 2016). The final closure of the Paleo-Asian Ocean in NE China was along the Solonker-Xar Moron-Changchun-Yanji suture (SXCYS), and this was largely completed in the Late Permian, although activity continued into the Triassic (Wilde, 2015). Thereafter (Late Permian-Early Triassic), the tectonic setting of NE China changed from one dominated by north/south-directed movement to one dominated by east/west movement when the Paleo-Pacific plate motion became the dominant tectonic control (Li, 2006; Wilde, 2015; Wang et al., 2016; Liu et al., 2017 and references therein). Thus, the Haigou gold deposit ( $310 \mathrm{Ma}$ ) was emplaced before the onset of tectonism associated with the Paleo-Pacific Ocean subduction, but was temporally associated with the Paleo-Asian subduction. The location of this deposit in the southern part of the SXCYS is consistent with the hypothesis that gold mineralization in NE China was closely related to Mid-Late Paleozoic magmatism (330 to $310 \mathrm{Ma}$ ), localized in an island arc setting along the craton margin. This hypothesis is supported by the occurrence of several Late Paleozoic-Early Triassic subduction-accretion metamorphic complexes along the SXCYS, e.g., the Shitoukoumen-Yantongshan piemontite-schist, the Hulan complex, the Seluohe complex, the Qinglongcun complex and the Kaishantun complex (Zhou et al., 2013), as well as the Permian granite belt along the Dunhua-Yanji (Sun et al., 2013), all of which indicate an island arc setting for NE China in the Late Paleozoic. 

magmatism are common between the southern segment of the CAOB and the northern margin of the

531 NCC and the Tarim Craton, almost all of them occur in the western segment of the CAOB (e.g., Shen et

532

533

534 al., 2014; Dong et al., 2018; Wang et al., 2018). The reason why the eastern part of this important metallogenic belt seems to be largely devoid of Paleozoic lode gold deposits is unclear. It is possible that, as was the case for the Haigou deposit, they have not been correctly dated. Thus, as most of the gold deposits in the eastern САОВ have been dated using the Ar-Ar method, they may be Paleozoic deposits that were affected by later magmatic events. Alternatively, granitoid magmatism may have been much less voluminous in the Paleozoic than in the Mesozoic when subduction of the Paleo-Pacific plate was associated with slab retreat/roll-back that resulted in regional thinning and delamination of the lithosphere and promoted this type of magmatism (e.g., Wu et al., 2011; Wilde, 2015; Zhou et al., 2018). Nevertheless, there is a significant number of granitoids in the eastern CAOB of similar age to the Haigou granitoid stock, e.g., the Silengshan, Xincuntun, and Jinxing stocks (Liu et al., 2009; Wu et al., 2011). Irrespective of the reason for the apparent lack of Paleozoic lode gold deposits in the eastern $\mathrm{CAOB}$, the new Re-Os and zircon U-Pb data reported in this study, providing evidence of Paleozoic gold mineralization at Haigou, suggest that gold exploration strategies in the region may need to be reevaluated.

Systematic Re-Os dating of molybdenite shown to be spatially and temporally associated with gold mineralization in the Haigou lode Au deposit, one of the largest gold deposits in the eastern CAOB, has shown that, contrary to the results of earlier studies, the deposit was emplaced during the Paleozoic (310-312 Ma) and not the Late Mesozoic. This age is consistent with U-Pb zircon ages determined for the host monzogranite and monzonite of $327 \mathrm{Ma}$ and $329 \mathrm{Ma}$, respectively, and a zircon U-Pb age of $310 \mathrm{Ma}$ for a dike parallel to the auriferous veins and therefore potentially syn-ore. The new geochronological data reported here provide clear evidence for a Late Paleozoic gold mineralization event in the easternmost CAOB. The new Re-Os and U-Pb data suggest that gold exploration strategies in the region may need to be re-evaluated.

This study also demonstrates that accurate and reproducible molybdenite Re-Os ages require a combination of careful petrographic documentation, proper sampling procedures, relatively large aliquots for analysis, particularly if the Re contents are low, and multiple analyses of individual samples. In geological environments affected by multiple thermal events, Re-Os geochronology may provide the only means of reliably determining the true age of mineralization, and in all cases Ar-Ar ages should be treated with caution because of the ease with which thermal disturbances can overprint the oreforming event.

\section{Acknowledgement}

This research was supported financially by the China National Gold Group Corporation (ZJ-DZ/2015JLHG), the National Key R\&D Program of China (2017YFC0601306), the MOST Special Fund from the State Key Laboratory of Geological Processes and Mineral Resources, China University of Geosciences 
(MSFGPMR201804), the Chinese "111" project (B07011), and an international visiting program grant from the Fundamental Research Funds for the Central Universities, China for DZ to visit Canada, where the writing of the manuscript was completed. DS acknowledges the Total Endowment Fund and a CUG (Wuhan) scholarship. The study could not have been done without the help in the field of the staff of the Haigou mine and the China Gold mining company. We are also grateful to Li Su and Hongyu Zhang (CUGB) for carrying out the U-Pb analyses, to Dongjie Tang (CUGB) for the SEM analyses, to Lang Shi (McGill University) for the electron microprobe analyses, and to Yan Zhang (CAGS) for the Ar-Ar dating. Richard Goldfarb made very helpful suggestions after reading an early version of the manuscript that significantly improved the current version and Holly Stein provided important advice on the application of the molybdenite Re-Os chronometer and the reliability of the LA-ICP-MS Re-Os dating method. Finally, this manuscript benefitted considerably from the comments and suggestions of the two journal reviewers Drs. Nicolas Saintilan and Robert Creaser, the Associate Editor Massimo Chiaradia, and the Chief Editor Larry Meinert.

\section{References}

Black, L.P., Kamo, S.L., Allen, C.M., Aleinikoff, J.N., Davis, D.W., Korsch, R.J., and Foudoulis, C., 2003, TEMORA 1: a new zircon standard for Phanerozoic U-Pb geochronology: Chemical Geology, v. 200, p. 155-170.

Buret, Y., Wotzlaw, J.F., Roozen, S., Guillong, M., von Quadt, A., and Heinrich, C.A., 2017, Zircon petrochronological evidence for a plutonic-volcanic connection in porphyry copper deposits: Geology, v. 45 , p. 623-626.

Cao, K., Yang, Z.M., Mavrogenes, J., White, N.C., Xu, J.F., Li, Y., and Li, W.K., 2019, Geology and genesis of the giant Pulang porphyry Cu-Au district, Yunnan, southwest China: Economic Geology, v. 114, p. 275301.

Chai, P., Sun, J.G., Xing, S.W., Chen, L., and Han, J.L., 2016, Geochemistry, zircon U-Pb analysis, and fluid inclusion ${ }^{40} \mathrm{Ar} /{ }^{39} \mathrm{Ar}$ geochronology of the Yingchengzi gold deposit, southern Heilongjiang Province, NE China: Geological Journal, v. 51, p. 505-522.

Chang, J., Li, J.W., Selby, D., Liu, J.C., and Deng, X.D., 2017, Geological and chronological constraints on the long-lived Eocene Yulong porphyry Cu-Mo deposit, eastern Tibet: implications for the lifespan of giant porphyry Cu deposits: Economic Geology, v. 112, p. 1719-1746.

Chang, Y., Zhang, Y., Sun, J.G., Chai, P., Li, L., and Yang, F., 2013, The dynamothermal source of gold mineralization, Haigou deposit: evidence from zircon $\mathrm{CL}$ image and $\mathrm{U}-\mathrm{Pb}$ dating: Journal of Mineralogy and Petrology, v. 33, p. 35-42 (in Chinese with English abstract).

Chelle-Michou, C., Chiaradia, M., Béguelin, P., and Ulianov, A., 2015b, Petrological evolution of the magmatic suite associated with the Coroccohuayco $\mathrm{Cu}$ (-Au-Fe) porphyry-skarn deposit, Peru: Journal of Petrology, v. 56, p. 1829-1862.

Chelle-Michou, C., Chiaradia, M., Ovtcharova, M., Ulianov, A., and Wotzlaw, J.F., 2014, Zircon petrochronology reveals the temporal link between porphyry systems and the magmatic evolution of their hidden plutonic roots (the Eocene Coroccohuayco deposit, Peru): Lithos, v. 198, p. 129-140. 
605

606

607

608

609

610

611

612

613

614

615

616

617

618

619

620

621

622

623

624

625

626

627

628

629

630

631

632

633

634

635

636

637

638

639

640

641

642

Chelle-Michou, C., Chiaradia, M., Selby, D., Ovtcharova, M., and Spikings, R.A., 2015a, High-resolution geochronology of the Coroccohuayco porphyry-skarn deposit, Peru: A rapid product of the Incaic Orogeny: Economic Geology, v. 110, p. 423-443.

Chen, B., Jahn, B.M., Wilde, S., and Xu, B., 2000, Two contrasting Paleozoic magmatic belts in northern Inner Mongolia, China: petrogenesis and tectonic implications: Tectonophysics, v. 328, p. 157-182.

Chen, W., Zhang, Y., Zhang, Y.Q., Jin, G.S., and Wang, Q.L., 2006, Late Cenozoic episodic uplifting in southeastern part of the Tibetan plateau-evidence from Ar-Ar thermochronology: Acta Petrologica Sinica, v. 22, p. 867-872 (in Chinese with English abstract).

Chen, X., Seitmuratova, E., Wang, Z., Chen, Z., Han, S., Li, Y., Yang, Y., Ye, B., and Shi, W., 2014, SHRIMP $\mathrm{U}-\mathrm{Pb}$ and $\mathrm{Ar}-\mathrm{Ar}$ geochronology of major porphyry and skarn $\mathrm{Cu}$ deposits in the Balkhash Metallogenic Belt, Central Asia, and geological implications: Journal of Asian Earth Sciences, v. 79, p. 723-740.

Chen, Y.J., Zhang, C., Wang, P., Pirajno, F., and Li, N., 2017, The Mo deposits of Northeast China: a powerful indicator of tectonic settings and associated evolutionary trends: Ore Geology Reviews, v. 81, p. $602-640$.

Cheng, Z., Zhang, Z., Chai, F., Hou, T., Santosh, M., Turesebekov, A., and Nurtaev, B.S., 2018, Carboniferous porphyry $\mathrm{Cu}-\mathrm{Au}$ deposits in the Almalyk orefield, Uzbekistan: the Sarycheku and Kalmakyr examples: International Geology Review, v. 60, p. 1-20.

Chiaradia, M., Merino, D., and Spikings, R., 2009a, Rapid transition to long-lived deep crustal magmatic maturation and the formation of giant porphyry-related mineralization (Yanacocha, Peru): Earth and Planetary Science Letters, v. 288, p. 505-515.

Chiaradia, M., Schaltegger, U., and Spikings, R.A., 2014, Time scales of mineral systems-advances in understanding over the past decade. Soc: Economic Geology, v. 18, p. 37-58.

Chiaradia, M., Schaltegger, U., Spikings, R., Wotzlaw, J.F., and Ovtcharova, M., 2013, How accurately can we date the duration of magmatic-hydrothermal events in porphyry systems?-an invited paper: Economic Geology, v. 108, p. 565-584.

Chiaradia, M., Vallance, J., Fontboté, L., Stein, H., Schaltegger, U., Coder, J., Richards, J., Villeneuve, M., and Gendall, I., 2009b, U-Pb, Re-Os, and ${ }^{40} \mathrm{Ar} /{ }^{39} \mathrm{Ar}$ geochronology of the Nambija Au skarn and Pangui porphyry-Cu deposits, Ecuador: Implications for the Jurassic metallogenic belt of the Northern Andes: Mineralium Deposita, v. 44, p. 371-387.

Ciobanu, C.L., Cook, N.J., Kelson, C.R., Guerin, R., Kalleske, N., and Danyushevsky, L., 2013, Trace element heterogeneity in molybdenite fingerprints stages of mineralization: Chemical Geology, v. 347, p. 175189.

Creaser, R.A., Papanastassiou, D.A., and Wasserburg, G.J., 1991, Negative thermal ion mass spectrometry of osmium, rhenium and iridium: Geochimica et Cosmochimica Acta, v. 55, p. 397-401.

Deng, J., Yang, L., Gao, B., Sun, Z., Guo, C., Wang, Q., and Wang, J., 2009, Fluid evolution and metallogenic dynamics during tectonic regime transition: example from the Jiapigou gold belt in Northeast China: Resource Geology, v. 59, p. 140-152.

Dong, L., Wan, B., Yang, W., Deng, C., Chen, Z., Yang, L., Cai, K., and Xiao, W., 2018, Rb-Sr geochronology 
643

644

645

646

647

648

649

650

651

652

653

654

655

656

657

658

659

660

661

662

663

664

665

666

667

668

669

670

671

672

673

674

675

676

677

678

679

680

of single gold-bearing pyrite grains from the Katbasu gold deposit in the South Tianshan, China and its geological significance: Ore Geology Reviews, v. 100, p. 99-110.

Du, A., He, H., Yin, N., Zou, X., Sun, Y., Sun, D., Chen, S., and Qu, W., 1995, A study of the rheniumosmium geochronometry of molybdenite: Acta Petrologica Sinica (English Ed.), v. 8, p. 171-181.

Du, A., Wu, S., Sun, D., Wang, S., Qu, W., Markey, R., Stein, H., Morgan, J., and Malinovskiy, D., 2004, Preparation and certification of Re-Os dating reference materials: molybdenites HLP and JDC: Geostands and Geoanalytical Research, v. 28, p. 41-52.

Eizenhöfer, P.R., and Zhao, G., 2018, Solonker Suture in East Asia and its bearing on the final closure of the eastern segment of the Palaeo-Asian Ocean: Earth-Science Reviews, v. 186, p. 153-172.

Feng, S.Z., 1998, Geological characteristics and metallogenic mechanism of Haigou gold deposit, Jilin Province: Journal of Precious Metallic Geology, v. 4, p. 288-292 (in Chinese with English abstract).

Gao, J., Klemd, R., Zhu, M., Wang, X., Li, J., Wan, B., Xiao, W., Zeng, Q., Shen, P., Sun, J., and Qin, K., 2018, Large-scale porphyry-type mineralization in the Central Asian metallogenic domain: A review: Journal of Asian Earth Sciences, v. 165, p. 7-36.

Goldfarb, R.J., Taylor, R.D., Collins, G.S., Goryachev, N.A., and Orlandini, O.F., 2014, Phanerozoic continental growth and gold metallogeny of Asia: Gondwana Research, v. 25, p. 48-102.

Hart, C.J., Goldfarb, R.J., Qiu, Y., Snee, L., Miller, L.D., and Miller, M.L., 2002, Gold deposits of the northern margin of the North China Craton: multiple late Paleozoic-Mesozoic mineralizing events: Mineralium Deposita, v. 37, p. 326-351.

Huang, X.W., Qi, L., Gao, J.F., and Zhou, M.F., 2013, First reliable Re-Os ages of pyrite and stable isotope compositions of $\mathrm{Fe}(-\mathrm{Cu})$ deposits in the Hami region, eastern Tianshan Orogenic Belt, NW China: Resource Geology, v. 63, p. 166-187.

Hurtig, N.C., and Williams-Jones, A.E., 2014, An experimental study of the solubility of MoO3 in aqueous vapour and low to intermediate density supercritical fluids: Geochimica et Cosmochimica Acta, v. 136, p. 169-193.

JBGMR (Bureau of Geology and Mineral Resources of Jilin Province), 1988, Regional Geology of Jilin Province. Geological Publishing House, Beijing, 698p (in Chinese).

Jiao, B.Q., Li, S.P., Wang, Y.P., Tao, S.H., Piao, Y., and Zhao, K., 2008, Diagenetic epoch and genesis of Haigou rock bodies: Jilin Geology, v. 27, p. 1-4 (in China with English abstract).

Lawley, C.J.M., and Selby, D., 2012, Re-Os geochronology of quartz-enclosed ultrafine molybdenite: Implications for ore geochronology: Economic Geology, v. 107, p. 1499-1505.

Li, J.W., Bi, S.J., Selby, D., Chen, L., Vasconcelos, P., Thiede, D., Zhou, M.F., Zhao, X.F., Li, Z.K., and Qiu, H.N., 2012, Giant Mesozoic gold provinces related to the destruction of the North China craton: Earth and Planetary Science Letters, v. 349, p. 26-37.

Li, J.W., Vasconcelos, P., Zhou, M.F., Zhao, X.F., and Ma, C.Q., 2006, Geochronology of the Pengjiakuang and Rushan gold deposits, eastern Jiaodong gold province, northeastern China: implications for regional mineralization and geodynamic setting: Economic Geology, v. 101, p. 1023-1038.

Li, J.Y., 2006, Permian geodynamic setting of Northeast China and adjacent regions: closure of the 
681 Paleo-Asian Ocean and subduction of the Paleo-Pacific Plate: Journal of Asian Earth Sciences, v. 26, p.

682 207-224.

683 Li, L., Sun, J., Men, L., and Chai, P., 2017, Genesis of the Haigou gold deposit, Jilin Province, NE China: 684 evidence from fluid inclusions, ${ }^{40} \mathrm{Ar} /{ }^{39} \mathrm{Ar}$ geochronology and isotopes: Geological Journal, v. 52, p. $992-$ 6851008

686 Li, X.C., Zhou, M.F., Williams-Jones, A.E., Yang, Y.H., and Gao, J.F., 2019, Timing and genesis of Cu-(Au) 687 mineralization in the Khetri Copper Belt, northwestern India: constraints from in situ $\mathrm{U}-\mathrm{Pb}$ ages and 688 Sm-Nd isotopes of monazite-(Ce): Mineralium Deposita, v. 54, p. 553-568.

689 Li, X.J., Fan, W.L., Wang, J.Y., Fan, W.S., Liang, B.S., Fan, Z.H., Yang, X.M., and Ren, D.K., 2012, U-Pb dating 690 of syn-mineralization dykes of the Haigou gold deposit, Jilin Province and its metallogenic significance: 691 Journal of Jilin Univeristy (Earth Science Edition), v. 42, p. 1366-1377 (in Chinese with English abstract). 692 Li, Y., Li, X.H., Selby, D., and Li, J.W., 2018, Pulsed magmatic fluid release for the formation of porphyry 693 deposits: Tracing fluid evolution in absolute time from the Tibetan Qulong Cu-Mo deposit: Geology, v. 46, 694 p. 7-10.

695 Li, Y., Selby, D., Condon, D., and Tapster, S., 2017, Cyclic magmatic-hydrothermal evolution in porphyry 696 systems: High-precision U-Pb and Re-Os geochronology constraints on the Tibetan Qulong porphyry Cu697 Mo deposit: Economic Geology, v. 112, p. 1419-1440.

698 Liu, J.F., Chi, X.G., Zhang, X.Z., Ma, Z.H., Zhao, Z., Wang, T.F., Hu, Z.C., and Zhao, X.Y., 2009, Geochemical 699 characteristics of Carboniferous quartz diorite in the southern Xiwuqi area, Inner Mongolia and its 700 tectonic significance: Acta Geologica Sinica, v. 83, p. 365-376 (in Chinese with English abstract).

701 Liu, K., Zhang, J., Wilde, S.A., Zhou, J., Wang, M., Ge, M., Wang, J., and Ling, Y., 2017, Initial subduction 702 of the Paleo-Pacific Oceanic plate in NE China: Constraints from whole-rock geochemistry and zircon U$703 \mathrm{~Pb}$ and Lu-Hf isotopes of the Khanka Lake granitoids: Lithos, v. 274-275, p. 254-270.

704 Liu, Y., Li, W., Feng, Z., Wen, Q., Neubauer, F., and Liang, C., 2016, A review of the Paleozoic tectonics in 705 the eastern part of Central Asian Orogenic Belt: Gondwana Research, v. 43, p. 123-148.

706 Liu, Y.S., Hu, Z.C., Gao, S., Günther, D., Xu, J., Gao, C.G., and Chen, H.H., 2008, In situ analysis of major 707 and trace elements of anhydrous minerals by LA-ICP-MS without applying an internal standard: 708 Chemical Geology, v. 257, p. 34-43.

709 Ludwig. K.R., 2003, User's manual for Isoplot 3.0: a geochronological toolkit for Microsoft excel. 710 Berkeley Geochronology Centre, Special Publication.

711 Mao, J., Pirajno, F., Lehmann, B., Luo, M., and Berzina, A., 2014, Distribution of porphyry deposits in the 712 Eurasian continent and their corresponding tectonic settings: Journal of Asian Earth Sciences, v. 79, p. 713 576-584.

714 Markey, R., Stein, H.J., Hannah, J.L., Zimmerman, A., Selby, D., and Creaser, R.A., 2007, Standardizing 715 Re-Os geochronology: a new molybdenite reference material (Henderson, USA) and the stoichiometry 716 of Os salts: Chemical Geology, v. 244, p. 74-87.

717 Morelli, R.M., Bell, C.C., Creaser, R.A., and Simonetti, A., 2010, Constraints on the genesis of gold 718 mineralization at the Homestake Gold Deposit, Black Hills, South Dakota from rhenium-osmium sulfide 
geochronology: Mineralium Deposita, v. 45, p. 461-480.

Ootes, L., Morelli, R.M., Creaser, R.A., Lentz, D.R., Falck, H., and Davis, W.J., 2011, The timing of Yellowknife gold mineralization: A temporal relationship with crustal anatexis?: Economic Geology, $v$. 106, p. 713-720.

Ouyang, H., Mao, J., Zhou, Z., and Su, H., 2015, Late Mesozoic metallogeny and intracontinental magmatism, southern Great Xing'an Range, northeastern China: Gondwana Research, v. 27, p. 11531172.

Porter, S.J., and Selby, D., 2010, Rhenium-Osmium (Re-Os) molybdenite systematics and geochronology of the Cruachan Granite skarn mineralization, Etive Complex: implications for emplacement chronology: Scottish Journal of Geology, v. 46, p. 17-21.

Qi, L., Zhou, M.F., Gao, J., and Zhao, Z., 2010, An improved Carius tube technique for determination of low concentrations of Re and Os in pyrites: Journal of Analytical Atomic Spectrometry, v. 25, p. 585-589. Rathkopf, C., Mazdab, F., Barton, I., and Barton, M.D., 2017, Grain-scale and deposit-scale heterogeneity of Re distribution in molybdenite at the Bagdad porphyry Cu-Mo deposit, Arizona: Journal of Geochemical Exploration, v. 178, p. 45-54.

Saintilan, N.J., Creaser, R.A., and Bookstrom, A.A., 2017a, Re-Os systematics and geochemistry of cobaltite (CoAsS) in the Idaho Cobalt belt, Belt-Purcell Basin, USA: Evidence for middle Mesoproterozoic sediment-hosted Co-Cu sulfide mineralization with Grenvillian and Cretaceous remobilization: Ore Geology Reviews, v. 86, p. 509-525.

Saintilan, N.J., Creaser, R.A., Spry, P.G., and Hnatyshin, D., 2017b, Re-Os systematics of löllingite and arsenopyrite in granulite-facies garnet rocks: Insights into the metamorphic history and thermal evolution of the Broken Hill Block during the Early Mesoproterozoic (new South Wales, Australia): The Canadian Mineralogist, v. 55, p. 29-44.

Saintilan, N.J., Selby, D., Creaser, R.A., and Dewaele, S., 2018, Sulphide Re-Os geochronology links orogenesis, salt and Cu-Co ores in the Central African Copperbelt: Scientific reports, v. 8, p. 14946.

Selby, D., and Creaser, R.A., 2001a, Re-Os geochronology and systematics in molybdenite from the Endako porphyry molybdenum deposit, British Columbia, Canada: Economic Geology, v. 96, p. 197-204. Selby, D., and Creaser, R.A., 2001b, Late and mid-Cretaceous mineralization in the northern Canadian Cordillera: Constraints from Re-Os molybdenite dates: Economic Geology, v. 96, p. 1461-1467.

Selby, D., and Creaser, R.A., 2004, Macroscale NTIMS and microscale LA-MC-ICP-MS Re-Os isotopic analysis of molybdenite: Testing spatial restrictions for reliable Re-Os age determinations, and implications for the decoupling of Re and Os within molybdenite: Geochimica et Cosmochimica Acta, v. 68, p. 3897-3908.

Selby, D., Creaser, R.A., and Feely, M., 2004, Accurate and precise Re-Os molybdenite dates from the Galway Granite, Ireland. Critical comment on "Disturbance of the Re-Os chronometer of molybdenites from the late-Caledonian Galway Granite, Ireland, by hydrothermal fluid circulation" by Suzuki et al., Geochemical Journal, 35, 29-35, 2001: Geochemical Journal, v. 38, p. 291-294.

Selby, D., Creaser, R.A., Hart, C.J., Rombach, C.S., Thompson, J.F., Smith, M.T., Bakke, A.A., and Goldfarb, 
R.J., 2002, Absolute timing of sulfide and gold mineralization: A comparison of Re-Os molybdenite and Ar-Ar mica methods from the Tintina Gold Belt, Alaska: Geology, v. 30, p. 791-794.

Selby, D., Creaser, R.A., Heaman, L.M., and Hart, C.J., 2003, Re-Os and U-Pb geochronology of the Clear Creek, Dublin Gulch, and Mactung deposits, Tombstone Gold Belt, Yukon, Canada: absolute timing relationships between plutonism and mineralization: Canadian Journal of Earth Sciences, v. 40, p. 18391852.

Selby, D., Creaser, R.A., Stein, H. J., Markey, R.J., and Hannah, J.L., 2007, Assessment of the ${ }^{187}$ Re decay constant by cross calibration of Re-Os molybdenite and $\mathrm{U}-\mathrm{Pb}$ zircon chronometers in magmatic ore systems: Geochimica et Cosmochimica Acta, v. 71, p. 1999-2013.

Selby, D., Kelley, K.D., Hitzman, M.W., and Zieg, J., 2009, Re-Os sulfide (bornite, chalcopyrite, and pyrite) systematics of the carbonate-hosted copper deposits at Ruby Creek, southern Brooks Range, Alaska: Economic Geology, v. 104, p. 437-444.

Sengör, A.M.C., and Natal'in, B.A., 1996, Paleotectonics of Asia: fragments of a synthesis. In: Yin, A., Harrison, M. (Eds.), The Tectonic Evolution of Asia. Cambridge University Press, Cambridge, p. 486-641. Shen, P., Pan, H., and Dong, L., 2014, Yandong porphyry Cu deposit, Xinjiang, China-geology, geochemistry and SIMS U-Pb zircon geochronology of host porphyries and associated alteration and mineralization: Journal of Asian Earth Sciences, v. 80, p. 197-217.

Shen, Y.C., Zeng, Q.D., and Xie, H.Y., 1999, Location time of gold deposit in Jiapigou Haigou mineralization zone, Jilin Province: Gold Science and Technology, v. 2, p. 19-26 (in Chinese with English abstract). Shu, Q., Chang, Z., Lai, Y., Zhou, Y., Sun, Y., and Yan, C., 2016, Regional metallogeny of Mo-bearing deposits in northeastern China, with new Re-Os dates of porphyry Mo deposits in the northern Xilamulun district: Economic Geology, v. 111, p. 1783-1798.

Smoliar, M.I., Walker, R.J., and Morgan, J.W., 1996, Re-Os ages of group IIA, IIIA, IVA, and IVB iron meteorites: Science, v. 271, p. 1099-1102.

Steiger, R., and Jäger, E., 1977, Subcommission on geochronology: convention on the use of decay constants in geo- and cosmochronology: Earth and Planetary Science Letters, v. 36, p. 359-362.

Stein, H., and Hannah, J., 2015, Rhenium-osmium geochronology: Sulfides, shales, oils, and mantle. Rink W. J. and Thompson J. (Eds.), Encyclopedia of Scientific Dating Methods, Springer, Netherlands, p. 707-723.

Stein, H., Scherstén, A., Hannah, J., and Markey, R., 2003, Subgrain-scale decoupling of Re and ${ }^{187}$ Os and assessment of laser ablation ICP-MS spot dating in molybdenite: Geochimica et Cosmochimica Acta, v. 67, p. $3673-3686$.

Stein, H.J., 2014, Dating and tracing the history of ore formation. In Holland, H. D., and Turekian, K. K. (eds.), Treatise on Geochemistry, 2nd edn. Oxford: Elsevier, v. 13, p. 87-118.

Stein, H.J., Markey, R.J., Morgan, J.W., Hannah, J.L., and Scherstén, A., 2001, The remarkable Re-Os chronometer in molybdenite: how and why it works: Terra Nova, v. 13, p. 479-486.

Stein, H.J., Morgan, J.W., and Scherstén, A., 2000, Re-Os dating of low-level highly radiogenic (LLHR) sulfides: The Harnas gold deposit, southwest Sweden, records continental-scale tectonic events: 
Economic Geology, v. 95, p. 1657-1671.

Stein, H.J., Morgan, J.W., Markey, R.J., and Hannah, J.L., 1998, An introduction to Re-Os: What's in it for the mineral industry?: Society of Economic Geology Newsletters, v. 32, p. 1-15.

Su, W., Hu, R., Xia, B., Xia, Y., and Liu, Y., 2009, Calcite Sm-Nd isochron age of the Shuiyindong Carlintype gold deposit, Guizhou, China: Chemical Geology, v. 258, p. 269-274.

Sun, Y.W., Li, M.S., Ge, W.C., Zhang, Y.L., and Zhang, D.J., 2013, Eastward termination of the SolonkerXar Moron River Suture determined by detrital zircon $\mathrm{U}-\mathrm{Pb}$ isotopic dating and Permian floristics: Journal of Asian Earth Sciences, v. 75, p. 243-250.

Terada, K., Osaki, S., Ishihara, S., and Kiba, T., 1971, Distribution of rhenium in molybdenites from Japan: Geochemical Journal, v. 4, p. 123-141.

Völkening, J., Walczyk, T., and Heumann, K.G., 1991, Osmium isotope ratio determinations by negative thermal ionization mass spectrometry: International Journal of Mass Spectrometry and Ion Processes, $v$. 105, p. 147-159.

Von Quadt, A., Erni, M., Martinek, K., Moll, M., Peytcheva, I., and Heinrich, C.A., 2011, Zircon crystallization and the lifetimes of ore-forming magmatic-hydrothermal systems: Geology, v. 39, p. 731734.

Von Quadt, A., Gallhofer, D., Guillong, M., Peytcheva, I., Waelle, M., and Sakata, S., 2014, U-Pb dating of CA/non-CA treated zircons obtained by LA-ICP-MS and CA-TIMS techniques: impact for their geological interpretation: Journal of Analytical Atomic Spectrometry, v. 29, p. 1618-1629.

Von Quadt, A., Peytcheva, I., Kamenov, B., Fanger, L., Heinrich, C.A., and Frank, M., 2002, The Elatsite porphyry copper deposit in the Panagyurishte ore district, Srednogorie zone, Bulgaria: U-Pb zircon geochronology and isotope-geochemical investigations of magmatism and ore genesis: Geological Society, London, Special Publications, v. 204, p. 119-135.

von Quadt, A., Wotzlaw, J.F., Buret, Y., Large, S.J., Peytcheva, I., and Trinquier, A., 2016, High-precision zircon U/Pb geochronology by ID-TIMS using new $10^{13}$ ohm resistors: Journal of Analytical Atomic Spectrometry, v. 31, p. 658-665.

Wang, B., Zhou, J.B., Wilde, S.A., Zhang, X.Z., and Ren, S.M., 2016, The timing of final closure along the Changchun-Yanji suture zone: Constraints from detrital zircon $\mathrm{U}-\mathrm{Pb}$ dating of the Triassic Dajianggang Formation, NE China: Lithos, v. 261, p. 216-231.

Wang, S.S., 1983, Age determinations of ${ }^{40} \mathrm{Ar}-{ }^{40} \mathrm{~K},{ }^{40} \mathrm{Ar}-{ }^{39} \mathrm{Ar}$ and radiogenic ${ }^{40} \mathrm{Ar}$ released characteristics on K-Ar geostandards of China: Chinese Journal of Geology, v. 4, p. 315-323 (in Chinese with English abstract).

Wang, Y.H., Xue, C.J., Liu, J.J., and Zhang, F.F., 2018, Origin of the subduction-related Carboniferous intrusions associated with the Yandong porphyry Cu deposit in eastern Tianshan, NW China: constraints from geology, geochronology, geochemistry, and $\mathrm{Sr}-\mathrm{Nd}-\mathrm{Pb}-\mathrm{Hf}-\mathrm{O}$ isotopes: Mineralium Deposita, v. 53, p. 629-647.

Wang, Y.H., Xue, C.J., Liu, J.J., Wang, J.P., Yang, J.T., Zhang, F.F., Zhao, Z.N., Zhao, Y.J., and Liu, B., 2015, Early Carboniferous adakitic rocks in the area of the Tuwu deposit, eastern Tianshan, NW China: Slab 
833

834

835

836

837

838

839

840

841

842

843

844

845

846

847

848

849

850

851

852

853

854

855

856

857

858

859

860

861

862

863

864

865

866

867

868

869

870

871

melting and implications for porphyry copper mineralization: Journal of Asian Earth Sciences, v. 103, p. 332-349.

Watanabe, Y., and Stein, H.J., 2000, Re-Os ages for the Erdenet and Tsagaan Suvarga porphyry Cu-Mo deposits, Mongolia and tectonic implications: Economic Geology, v. 95, p. 1537-1542.

Wiedenbeck, M., Alle, P., Corfu, F., Griffin, W.L., Meier, M., Oberli, F., Von Quadt, A., Roddick, J.C., and Spiegel, W., 1995, Three natural zircon standards for U-Th-Pb, Lu-Hf, trace element and REE analyses: Geostandards newsletter, v. 19, p. 1-23.

Wilde, S.A., 2015, Final amalgamation of the Central Asian Orogenic Belt in NE China: Paleo-Asian Ocean closure versus Paleo-Pacific plate subduction-A review of the evidence: Tectonophysics, v. 662, p. 345362.

Williams-Jones, A.E., and Migdisov, A.A., 2014, Experimental constraints on the transport and deposition of metals in ore-forming hydrothermal systems: Society of Economic Geology, v. 18, p. 7796.

Wu, F.Y, Sun, D.Y., Ge, W.C., Zhang, Y.B., Grant, M.L., Wilde, S.A., and Jahn, B.M., 2011, Geochronology of the Phanerozoic granitoids in northeastern China: Journal of Asian Earth Sciences, v. 41, p. 1-30.

Wu, F.Y., Wilde, S.A., Sun, D.Y., and Zhang, G.L., 2004, Geochronology and petrogenesis of postorogenic $\mathrm{Cu}, \mathrm{Ni}$-bearing mafic-ultramafic intrusions in Jilin, NE China: Journal of Asian Earth Sciences, v. 23, p. 781-797.

Wu, F.Y., Yang, J.H., Lo, C.H., Wilde, S.A., Sun, D.Y., and Jahn, B.M., 2007, The Heilongjiang Group: a Jurassic accretionary complex in the Jiamusi Massif at the western Pacific margin of northeastern China: Island Arc, v. 16, p. 156-172.

Xiao, W., Windley, B.F., Hao, J., and Zhai, M., 2003, Accretion leading to collision and the Permian Solonker suture, Inner Mongolia, China: termination of the central Asian orogenic belt: Tectonics, v. 22, p. 1609.

Xu, B., Zhao, P., Wang, Y.Y., Liao, W., Luo, Z.W., Bao, Q.Z., and Zhou, Y.H., 2015, The pre-Devonian tectonic framework of Xing'an-Monglia orogenic belt (XMOB) in north China: Journal of Asian Earth Sciences, $v$. 97, p. 183-196.

Yang, J.H., Wu, F.Y., and Wilde, S.A., 2003, A review of the geodynamic setting of large-scale Late Mesozoic gold mineralization in the North China Craton: an association with lithospheric thinning: Ore Geology Reviews, v. 23, p. 125-152.

Yang, Z., and Cooke, D.R., 2019, Porphyry copper deposits in China: SEG Special Publications, p. 1-55 (in press).

Yang, Z., Chang, Z., Hou, Z., and Meffre, S., 2016, Age, igneous petrogenesis, and tectonic setting of the Bilihe gold deposit, China, and implications for regional metallogeny: Gondwana Research, v. 34, p. 296314.

Yang, Z., Chang, Z., Paquette, J., White, N.C., Hou, Z., and Ge, L., 2015, Magmatic Au mineralization at the Bilihe Au deposit, China: Economic Geology, v. 110, p. 1661-1668.

Yu, J.J., Guo, J., and Cui, P.L., 2010, Ore-forming geologic settings and ${ }^{40} \mathrm{Ar} /{ }^{39} \mathrm{Ar}$ laser probe dating of fluid inclusions in quartzs from Haigou gold deposit, Yanbian City, Northeastern China: Journal of Jilin 
University (Earth Science Edition), v. 40, p. 835-844 (in Chinese with English abstract). Yuan, S., Peng, J., Hao, S., Li, H., Geng, J., and Zhang, D., 2011, In situ LA-MC-ICP-MS and ID-TIMS U-Pb geochronology of cassiterite in the giant Furong tin deposit, Hunan Province, South China: New constraints on the timing of tin-polymetallic mineralization: Ore Geology Reviews, v. 43, p. 235-242. Yuan, S., Peng, J., Hu, R., Li, H., Shen, N., and Zhang, D., 2008, A precise U-Pb age on cassiterite from the Xianghualing tin-polymetallic deposit (Hunan, South China): Mineralium Deposita, v. 43, p. 375-382. Zeng, Q., He, H., Zhu, R., Zhang, S., Wang, Y., and Su, F., 2017, Origin of ore-forming fluids of the Haigou gold deposit in the eastern Central Asian Orogenic belt, NE China: Constraints from HO-He-Ar isotopes: Journal of Asian Earth Sciences, v. 144, p. 384-397.

Zeng, Q., Liu, J., Chu, S., Wang, Y., Sun, Y., Duan, X., and Zhou, L., 2012, Mesozoic molybdenum deposits in the East Xingmeng orogenic belt, northeast China: characteristics and tectonic setting: International Geology Review, v. 54, p. 1843-1869.

Zeng, Q., Wang, Z., He, H., Wang, Y., Zhang, S., and Liu, J., 2014, Multiple isotope composition (S, Pb, H, $\mathrm{O}, \mathrm{He}$, and $\mathrm{Ar}$ ) and genetic implications for gold deposits in the Jiapigou gold belt, Northeast China: Mineralium Deposita, v. 49, p. 145-164.

Zeng, Q.D., Sun, Y., Duan, X.X., and Liu, J.M., 2013, U-Pb and Re-Os geochronology of the Haolibao porphyry Mo-Cu deposit, NE China: implications for a Late Permian tectonic setting: Geological Magazine, v. 150, p. 975-985.

Zhai D., Liu J., Wang J., Yang Y., Zhang, H., Wang, X., Zhang, Q., Wang, G., and Liu, Z., 2014a, Zircon U-Pb and molybdenite Re-Os geochronology, and whole-rock geochemistry of the Hashitu molybdenum deposit and host granitoids, Inner Mongolia, NE China: Journal of Asian Earth Sciences, v. 79, p. 144160.

Zhai, D., Liu J., Zhang, A., and Sun, Y., 2017, U-Pb, Re-Os and ${ }^{40} \mathrm{Ar} /{ }^{39} \mathrm{Ar}$ geochronology of porphyry Sn \pm $\mathrm{Cu} \pm \mathrm{Mo}$ and polymetallic (Ag-Pb-Zn-Cu) vein mineralization at Bianjiadayuan, Inner Mongolia, NE China: Implications for discrete mineralization events: Economic Geology, v. 112, p. 2041-2059.

Zhai, D., Liu, J., Cook, N.J., Wang, X., Yang, Y., Zhang, A., and Jiao, Y., 2019, Mineralogical, textural, sulfur and lead isotope constraints on the origin of Ag-Pb-Zn mineralization at Bianjiadayuan, Inner Mongolia, NE China: Mineralium Deposita, v. 54, p. 47-66.

Zhai, D., Liu, J., Ripley, E.M., and Wang, J., 2015, Geochronological and He-Ar-S isotopic constraints on the origin of the Sandaowanzi gold-telluride deposit, northeastern China: Lithos, v. 212, p. 338-352. Zhai, D., Liu, J., Tombros, S., and Williams-Jones, A.E., 2018a, The genesis of the Hashitu porphyry molybdenum deposit, Inner Mongolia, NE China: constraints from mineralogical, fluid inclusion, and multiple isotope (H, O, S, Mo, Pb) studies: Mineralium Deposita, v. 53, p. 377-397.

Zhai, D., Liu, J., Zhang, H., Tombros, S., and Zhang, A., 2018c, A magmatic-hydrothermal origin for Ag$\mathrm{Pb}-\mathrm{Zn}$ vein formation at the Bianjiadayuan deposit, inner Mongolia, NE China: Evidences from fluid inclusion, stable (C-H-O) and noble gas isotope studies: Ore Geology Reviews, v. 101, p. 1-16.

Zhai, D., Williams-Jones, A.E., Liu, J., Tombros, S.F., and Cook, N.J., 2018b, Mineralogical, fluid inclusion and multiple isotope (H-O-S-Pb) constraints on the genesis of the Sandaowanzi epithermal Au-Ag-Te 
910

911

912

913

914

915

916

917

918

919

920

921

922

923

924

925

926

927

928

929

930

931

932

933

934

935

936

937

deposit, NE China: Economic Geology, v. 113, p. 1359-1382.

Zhai, D.G., Liu, J.J., Zhang, H.Y., Yao, M.J., Wang, J.P., and Yang, Y.Q., 2014b, S-Pb isotopic geochemistry, $\mathrm{U}-\mathrm{Pb}$ and Re-Os geochronology of the Huanggangliang Fe-Sn deposit, Inner Mongolia, NE China: Ore Geology Reviews, v. 59, p. 109-122.

Zhang, J.H., Gao, S., Ge, W.C., Wu, F.Y., Yang, J.H., Wilde, S.A., and Li, M., 2010, Geochronology of the Mesozoic volcanic rocks in the Great Xing'an Range, northeastern China: implications for subductioninduced delamination: Chemical Geology, v. 276, p. 144-165.

Zhang, S., Wang, Y.B., and Chu, S.X., 2012, Zircon U-Pb ages and Sr-Nd-Hf isotopic composition of the Haigou granitoids at the northeastern margin of North China Craton: implications for geodynamic setting: Acta Petrologica Sinica, v. 28, p. 544-556 (in Chinese with English abstract).

Zhou, J.B., and Wilde, S.A., 2013, The crustal accretion history and tectonic evolution of the NE China segment of the Central Asian Orogenic Belt: Gondwana Research, v. 23, p. 1365-1377.

Zhou, J.B., Han, J., Wilde, S.A., Gou, X.D., Zeng, W.S., and Cao, J.L., 2013, A primary study of the JilinHeilongjiang high-pressure metamorphic belt: evidence and tectonic implication: Acta Petrologica Sinica, v. 29, p. 386-398.

Zhou, J.B., Wilde, S.A., Zhao, G.C., and Han, J., 2018, Nature and assembly of microcontinental blocks within the Paleo-Asian Ocean: Earth-Science Reviews, v. 186, p. 76-93.

Zhou, J.B., Wilde, S.A., Zhao, G.C., Zhang, X.Z., Zheng, C.Q., and Wang, H., 2010, New SHRIMP U-Pb Zircon ages fromthe Heilongjiang complex in NE China: constraints on theMesozoic evolution of NE China: American Journal of Sciences, v. 310, p. 1024-1053.

Zimmerman, A., Stein, H.J., Morgan, J.W., Markey, R.J., and Watanabe, Y., 2014, Re-Os geochronology of the El Salvador porphyry Cu-Mo deposit, Chile: Tracking analytical improvements in accuracy and precision over the past decade: Geochimica et Cosmochimica Acta, v. 131, p. 13-32.

\section{Figure captions}

Figure 1. (A) Tectonic elements of the Central Asian Orogenic Belt (CAOB, based on Zhai et al., 2018c); (B) Major tectonic units and sutures in the eastern CAOB (based on Wilde, 2015); (C) A geological map of the Jiapigou-Haigou gold belt in NE China showing the distribution of major gold deposits (modified from Zeng et al., 2014).

Figure 2. A geological map of the Haigou gold deposit (modified from Zhang et al., 2012).

Figure 3. (A) A geological map of the $407 \mathrm{~m}$ mining level (modified from Zeng et al., 2017); (B) A representative cross-section of the Haigou gold deposit; (C) Auriferous quartz veins hosted by monzonite with accompanying K-feldspar and quartz alteration; and (D) An auriferous quartz vein 
hosted by gneiss with pyrite-sericite alteration halo.

946

947

948

949

950

951

952

953

954

955

956

957

958

959

960

961

962

963

964

965

966

967

968

969

970

971

972

973

974

975

Figure 4. (A) Molybdenite veins and veinlets associated with K-feldspar near the margins of an auriferous quartz vein hosted by gneiss; (B) A sample containing fine-grained molybdenite as coatings on the surface of auriferous quartz veins and showing the results of Re-Os dating; (C) A sample containing relatively coarse-grained molybdenite as veins and veinlets in a quartz vein with a potassically altered wall-rock halo. The results of the Re-Os dating are shown.

Figure 5. A chart summarizing the mineral paragenesis of the Haigou Au deposit.

Figure 6. Photomicrographs showing the mode of gold occurrence in the Haigou deposit. (A) Coexisting native gold and galena filling fractures in pyrite (reflected light); (B) Native gold and electrum associated with galena, altaite, and coloradoite (reflected light); (C)-(D) Native gold intergrown with molybdenite and quartz (back scattered image); (E)-(F) Maps showing the distribution of Mo and Au in C and D. Abbreviations: Alt-altaite; Au-native gold; Col-coloradoite; Elt-electrum; Gn-galena; Mo-molybdenite; Py-pyrite; Qtz-quartz.

Figure 7. Element maps of molybdenite from the Haigou gold deposit. Abbreviations: Elt-electrum; Heshessite; Mo-molybdenite; Qtz-quartz.

Figure 8. Rhenium concentrations ( $\mathrm{ppm}$ ) in molybdenite of the Haigou gold deposit determined from in-situ LA-ICP-MS and electron microprobe analyses. (A) Locations of electron microprobe analyses and corresponding Re concentrations in fine-grained molybdenite (BSE) and (B)-(D) Locations of LA-ICP-MS spot analyses and Re distributions in coarse-grained molybdenite and its veins (reflected light).

Figure 9. Crosscutting relationships involving representative dikes and auriferous quartz veins and their zircon U-Pb ages. (A) A pre-ore porphyry dike with a zircon U-Pb age of $318.3 \pm 1.0 \mathrm{M}$ cut by a goldmineralized vein; (B) A vein-parallel andesite dike (possibly syn-ore) having a zircon U-Pb age of $310.9 \pm$ 1.1 Ma; (C) A post-ore diabase dike, which yielded a zircon U-Pb age of $134.9 \pm 0.4 \mathrm{Ma}$; (D) A vein parallel andesite dike which returned a zircon U-Pb age of $2446.5 \pm 9.0 \mathrm{Ma}$; (E) A granodiorite dike with a zircon U-Pb age of $259.8 \pm 0.4 \mathrm{Ma}$ displaying an unclear relationship with ore veins; (F) A post-ore diorite 
porphyry dike with a zircon age of $340.3 \pm 1.9 \mathrm{Ma}$; (G)-(I) Zircon U-Pb ages of $128.4 \pm 0.3,327.1 \pm 1.1$ and $329.5 \pm 1.0 \mathrm{Ma}$ for diorite, monzogranite and monzonite intrusions.

Figure 10. Re-Os model and isochron ages for molybdenite from the Haigou Au deposit. (A)-(B) Re-Os data for 16 molybdenite separates; (C)-(D) Re-Os data for 9 of the separates shown in A.

Figure 11. A sericite plateau Ar-Ar age (A) and isochron age (B) for the Haigou gold deposit.

Figure 12. Analyzed aliquot size versus model age for the molybdenite separates.

Figure 13. A summary of the timing of mineralization, hydrothermal alteration and magmatism in the Haigou gold deposit. Some of the U-Pb and Ar-Ar ages are from Feng (1998), Shen et al. (1999), Yu et al. (2010), Zhang et al. (2012), Chang et al. (2013), Zeng et al. (2017), and Li L et al. (2017).

\section{Supplementary data}

Figure A1. Re-Os isochron age for 13 pyrite separates from the Haigou gold deposit

Table A1. Results of electron microprobe analyses of Re concentrations in molybdenite from the Haigou gold deposit

Table A2. Results of LA-ICP-MS spot analyses of Re concentrations in molybdenite from the Haigou gold deposit

Table A3. Zircon U-Pb isotopic data obtained from LA-ICP-MS analyses of various igneous rocks from the Haigou gold deposit

Table A4. Re-Os data for pyrite from the Haigou gold deposit

Table A5. Results of ${ }^{40} \mathrm{Ar} /{ }^{39} \mathrm{Ar}$ age determinations of sericite from the Haigou gold deposit 


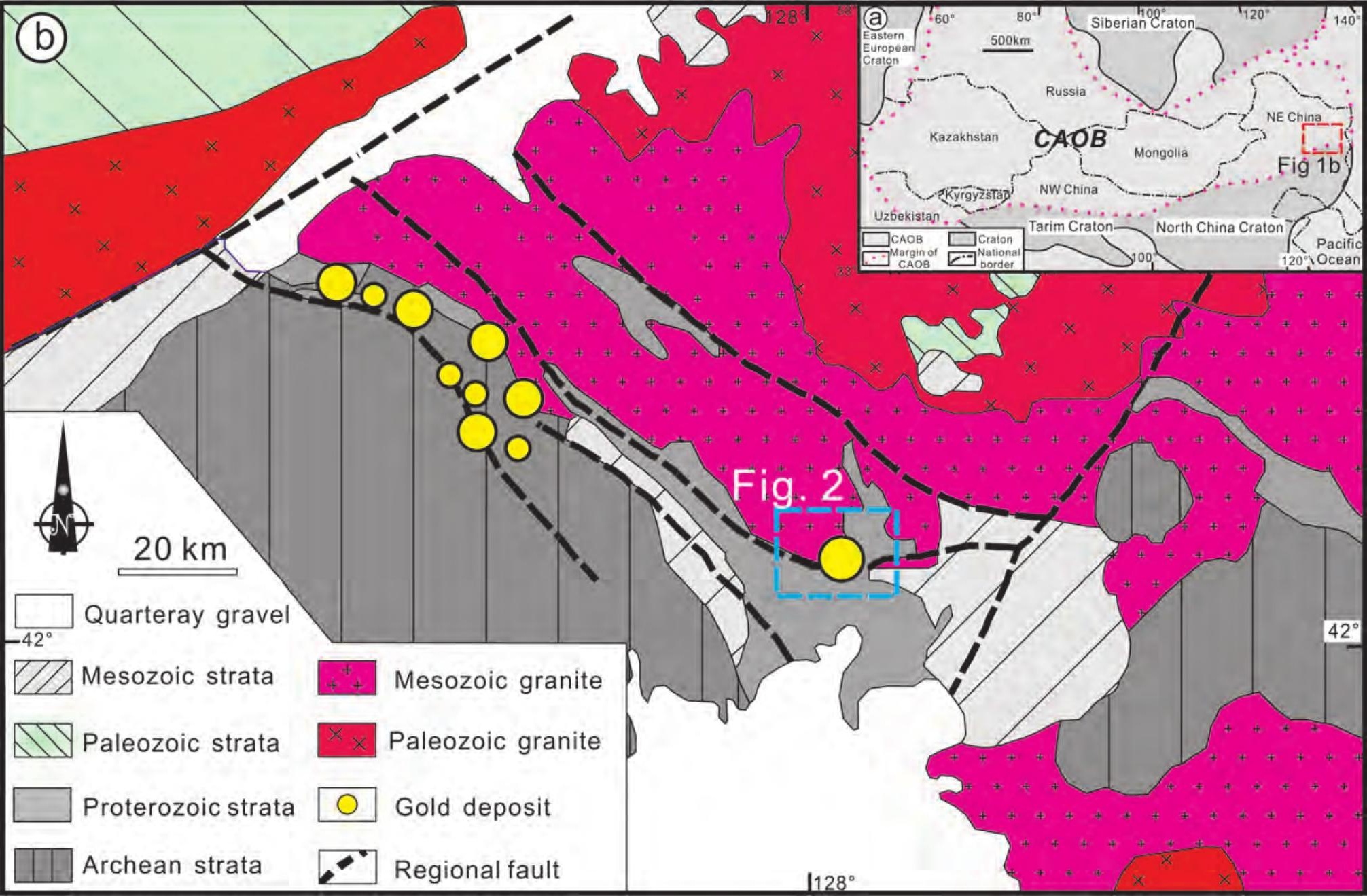




\section{a)}

\section{ax $y$}

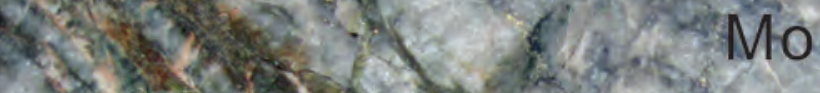

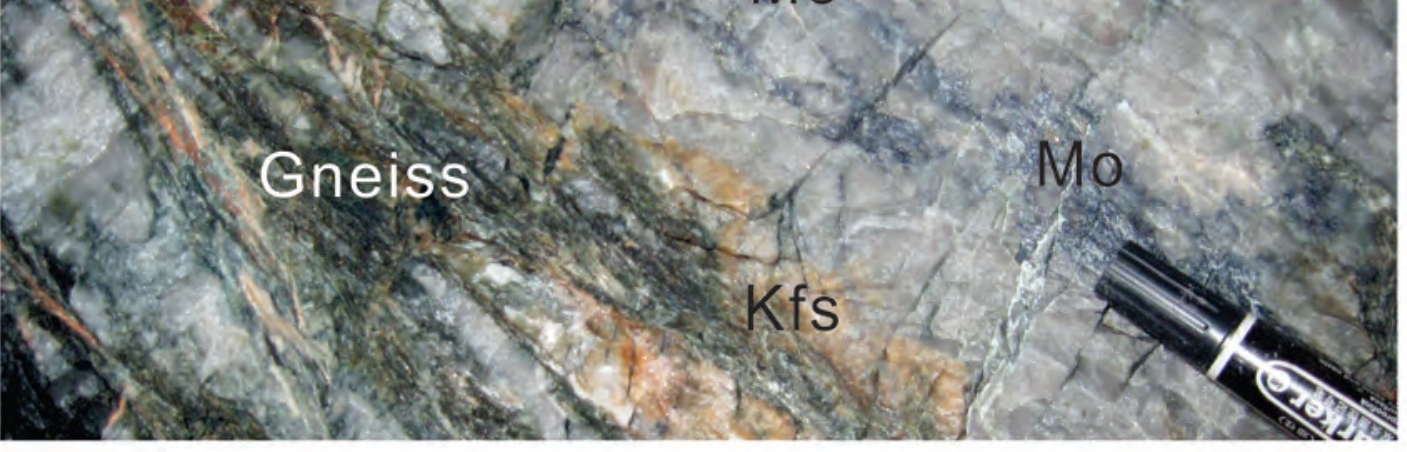

(b) $\mathrm{HG}-32$

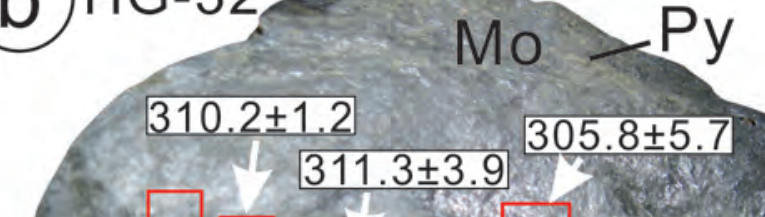

$\tan +\frac{1}{4}$ $306.7 \pm 1.2$

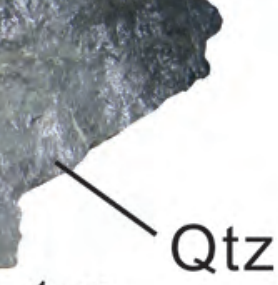

$155.3 \pm 1.8$ $307.9 \pm 4.0$ $1 \mathrm{~cm}$

HG-34

Qtz

Mo

(C)

Kfs

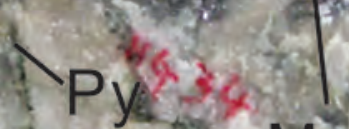
I. $\mathrm{MO}^{2}$

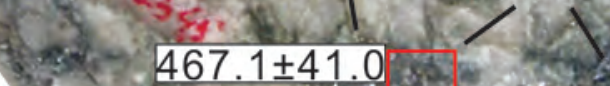

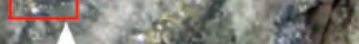

$2 \mathrm{~cm}$ $345.6 \pm 19.9$ 


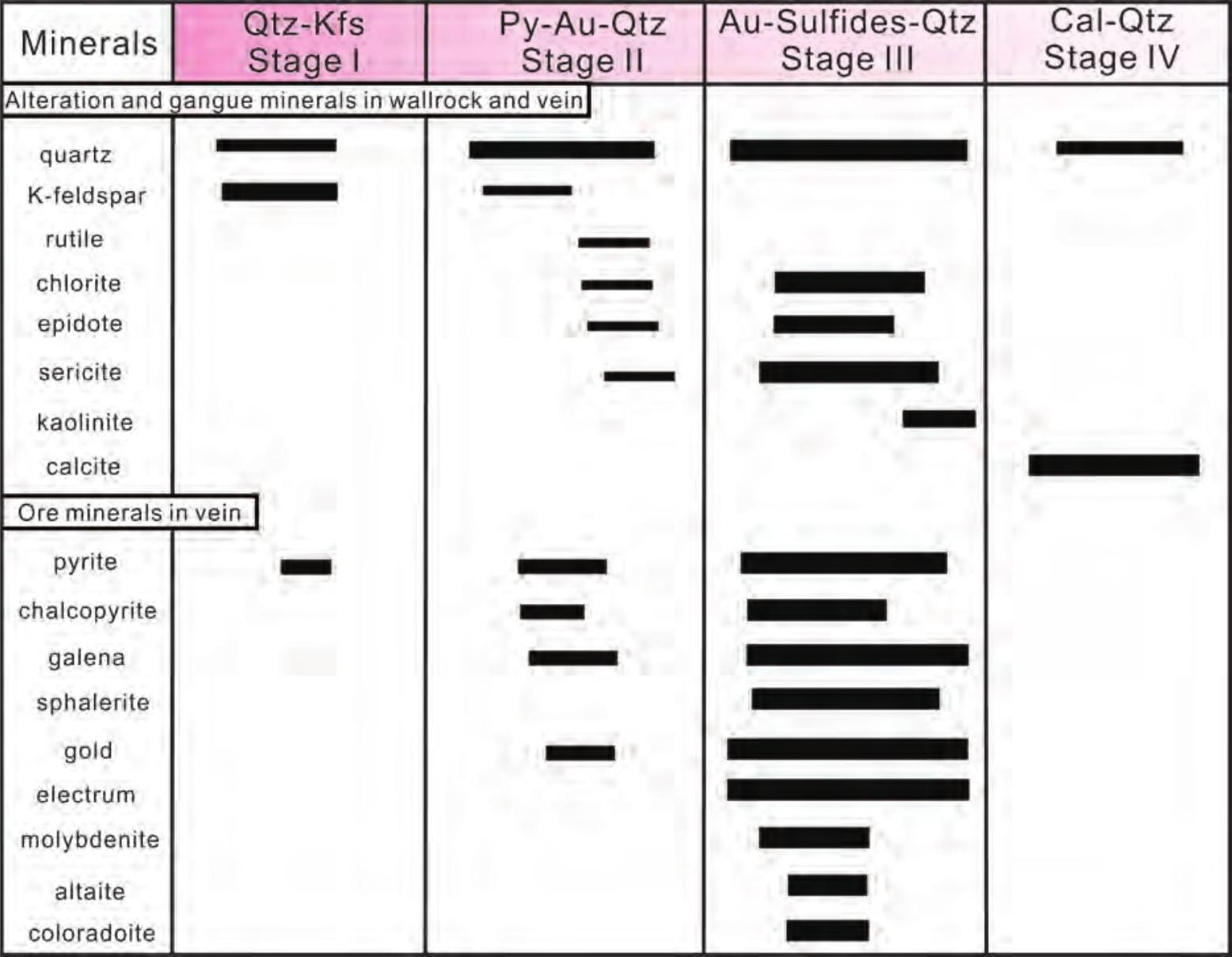




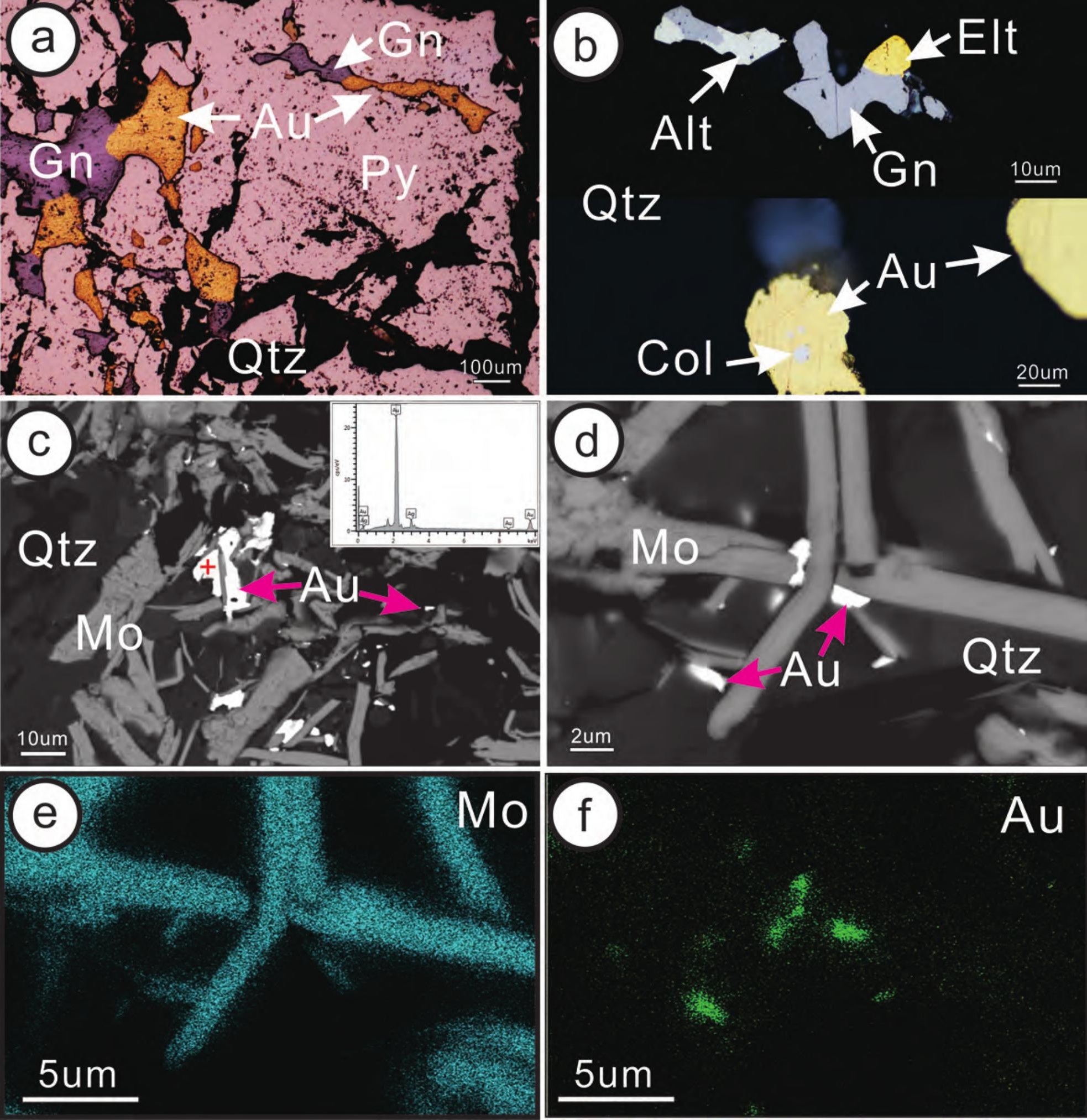




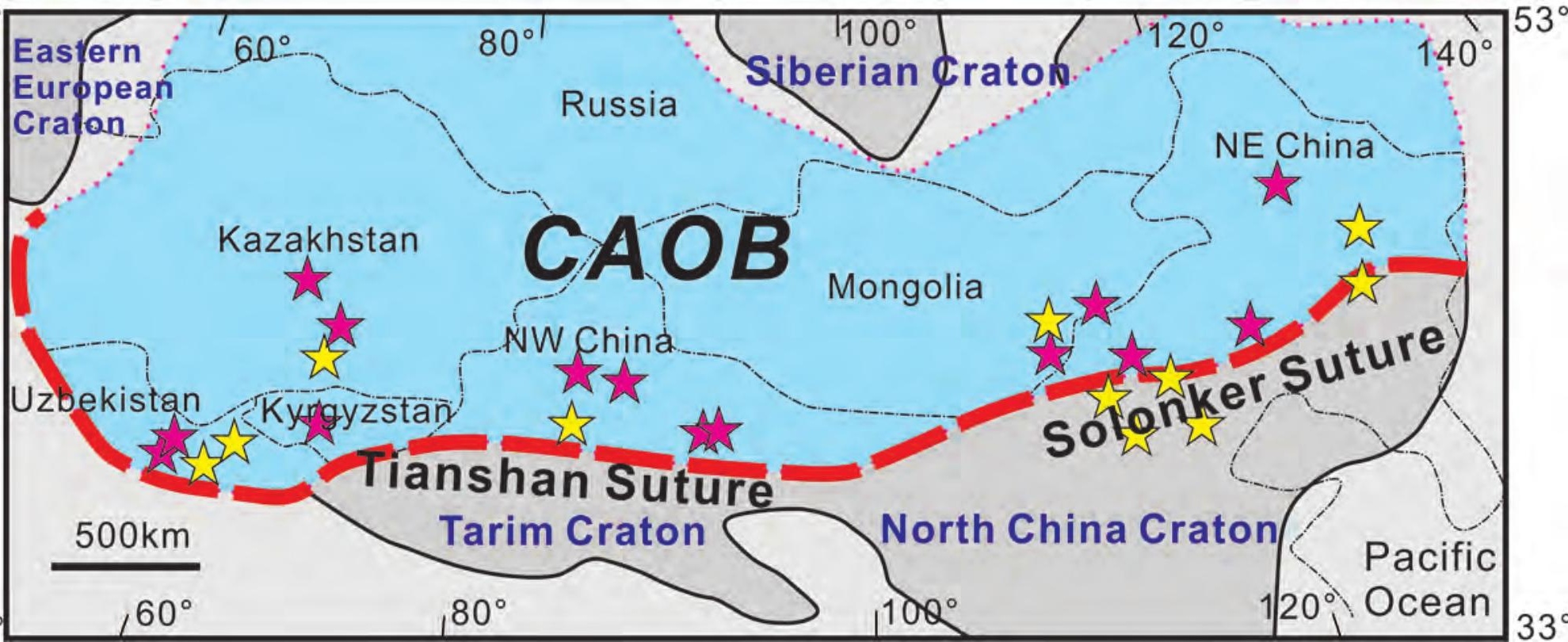

$153^{\circ}$ 